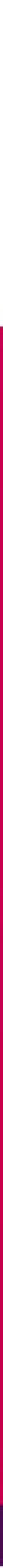





\section{国际教育标准分类法 2011}

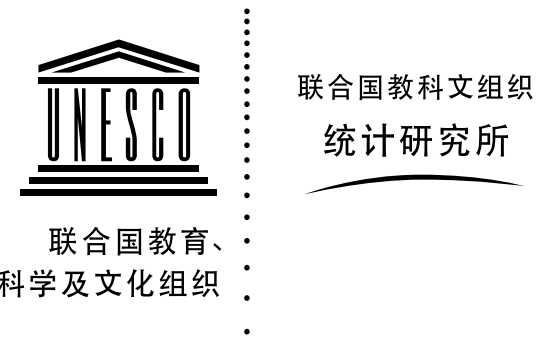




\section{联合国教科文组织（UNESCO）}

联合国教科文组织（UNESCO）宪章在1945年11月召开的伦敦大会上由20个国家通过，并于1946年11月4日生效。联合 国教科文组织目前有195个成员国和8个准会员。

联合国教科文组织的主要宗旨是致力于世界的和平与安定, 通过推动成员国在教育、科技、文化和信息领域的合作, 促进 对联合国宪章确认的无论种族、性别、语言或宗教、人人均应享有的正义、法治、人权和基本自由的普遍尊重。

为实现此目标, 联合国教科文组织履行以下五项主要职能：1）关于明日世界的教育、科技、文化和信息的前瞻性研 究；2）通过研究、培训和教育活动推进、传播和分享知识；3）标准制定活动, 起草和采用内部工具和法规建议；4）技 术合作专长，支持成员国的发展政策和项目；5）交流专门的信息。

联合国教科文组织总部设在法国巴黎。

\section{联合国教科文组织统计研究所}

联合国教科文组织统计研究所（UIS）是联合国教科文组织的统计机构，是教育、科技、文化和信息方面全球统计资料的 联合国保管者。

统计研究所成立于1999年。其成立的目的在于改善联合国教科文组织的统计项目, 编制和发布及时、准确且与政策相关 的统计资料, 以应对当今日益复杂多变的社会、政治和经济环境的需求。

联合国教科文组织统计研究所位于加拿大蒙特利尔。

联合国教科文组织统计研究所

2013年出版

地址: P.O. Box 6128, Succursale Centre-Ville Montreal, Quebec H3C 3J7

Canada

电话：(1514) 343-6880

邮箱： uis@unesco.org

网站：http://www.uis.unesco.org

ISBN 978-92-9189-135-1

Ref: UIS/2012/INS/10

OUNESCO-UIS 2013 


\section{前言}

各国教育系统的结构和课程内容各不相同，因此难以确定各国跨时期的成就的基准，或者对国家和国际 目标的实现进展进行监测。为了从全球角度解读并适当阐释教育系统的投入、过程和成果, 确保数据具 有可比性是不可或缺的。使用《国际教育标准分类法》 (ISCED) 这一标准框架, 分类和报告跨国的可 比性教育统计数据, 可以解决这个问题。

2011版《国际教育标准分类法》于2011年11月由联合国教科文组织大会第36届会议通过。最初于20世纪 70年代由联合国教科文组织开发，并于1997年首次修订， 《国际教育标准分类法》是收集和发布国家和 全球教育统计数据的一个工具。这一框架被不断更新以更好地捕捉世界教育系统的新进展。

2011版《国际教育标准分类法》包括对教育类型的定义的改善, 并阐明其在《国际教育标准分类法》中 的运用。等级分类中加入了类别, 以反映早期儿童教育的扩展和高等教育出现的结构调整。新增内容还 包括：

i) 引入教育资格证书，作为与教育课程一起的一个相关统计单元;

ii) 三数字编码系统, 用于教育课程和受教育程度等级;

iii) 一个关于《国际教育标准分类法》管理的章节; 以及

iv) 一个更丰富的词汇表。

这些改善内容由一个全球技术顾问组引进，该组成员是教育和统计学领域方面的国际专家，包括欧盟统 计局（Eurostat）和经济合作和开发组织 (OECD) 等相关国际组织及伙伴。其广泛的审查过程, 包括一 系列区域专家会议, 以及由联合国教科文组织统计研究所协调和教科文组织所有成员国受邀参与的一个 正式全球磋商。

联合国教科文组织统计研究所和联合国教科文组织一经济合作和开发组织一欧盟统计局的数据收集项目 将根据这些新的标准进行调整。教科文组织成员国将从2014年起使用2011版《国际教育标准分类法》上 报其教育统计数据。

2011版《国际教育标准分类法》反映全球教育系统的不断演进，将有助于获得更可靠和更具可比性的国 际教育统计数据。

2012年12月

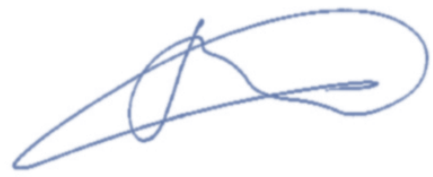

亨德里克·范德波尔

联合国教科文组织统计研究所 



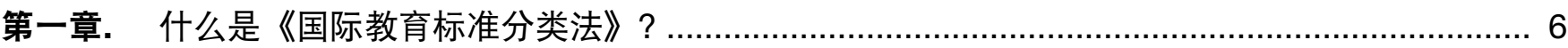

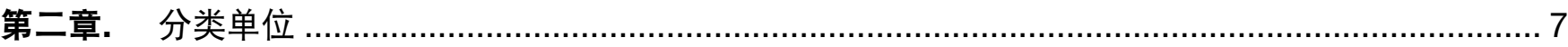

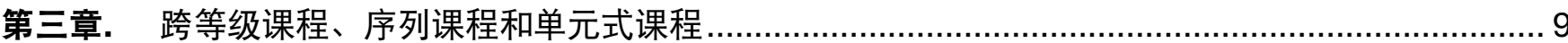

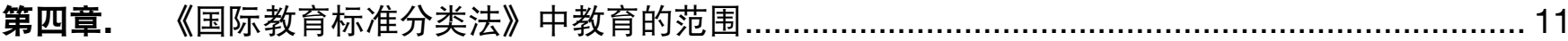

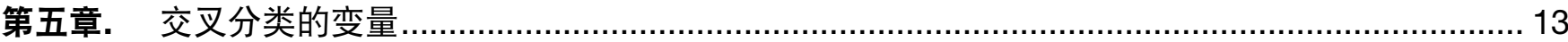

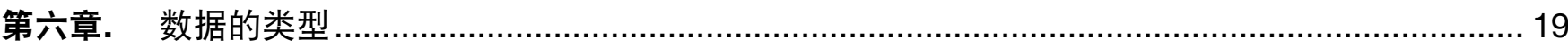

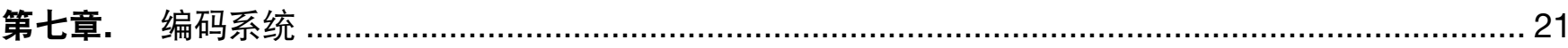

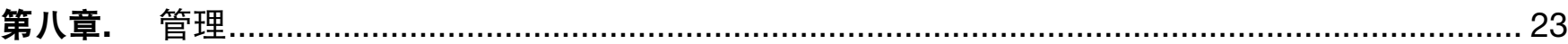

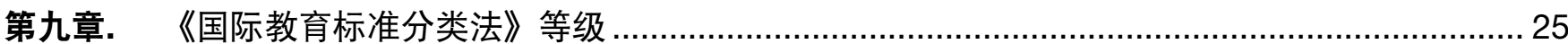

《国际教育标准分类法》0级 - 早期儿童教育 .................................................................. 26

《国际教育标准分类法》1级 - 初等教育.......................................................................... 30

《国际教育标准分类法》2级 - 初级中等教育 ................................................................ 33

《国际教育标准分类法》3级 - 高级中等教育 .............................................................. 38

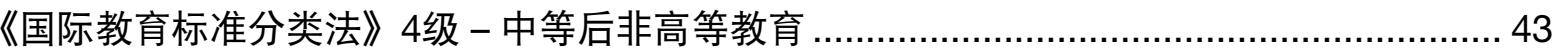

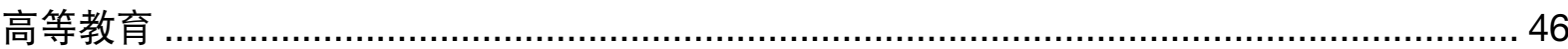

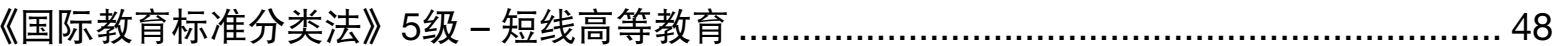

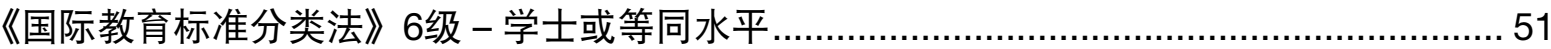

《国际教育标准分类法》 7 级 - 硕士或等同水平 ................................................................ 55

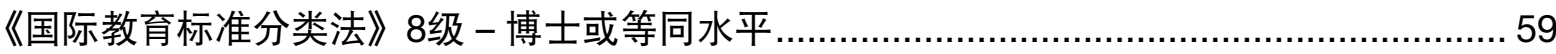

第十章. 《国际教育标准分类法》2011版与1997版的等级对应关系 .............................................6 62

附件I. 《国际教育标准分类法》2011版潜在教育路径 .................................................................. 68

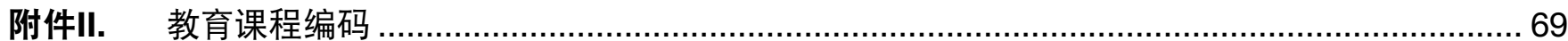

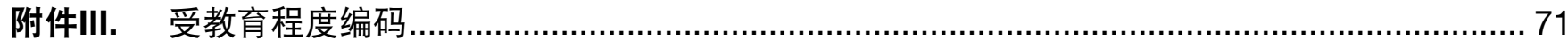

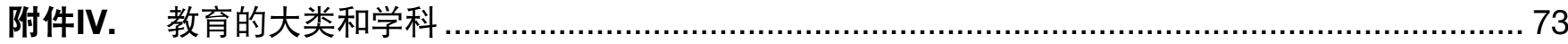

附件V. 《国际教育标准分类法》中的非正规教育：进一步的议题 .............................................. 76

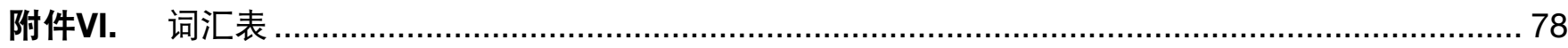




\section{什么是《国际教育标准分类法》?}

1. 《国际教育标准分类法》隶属于《联合国经济与社会分类法国际系列》，在世界统计中用于国家间 可比较数据的收集、汇编和分析。《国际教育标准分类法》是一个以教育等级和学科来整理教育课 程和相关资格证书的参考分类。《国际教育标准分类法》是国际协商的结果, 并经联合国教科文组 织成员国大会正式通过。

2. 制定《国际教育标准分类法》的目的，是提供一个框架，对由课程及资格证书所界定的教育活动， 按照国际公认的类别进行分类。《国际教育标准分类法》的基本概念和定义旨在能国际通用, 覆盖 所有教育系统。

3. 《国际教育标准分类法》采用以下两个主要的交叉分类变量, 按课程内容对教育课程进行分类: 教 育等级 (见第9章) 和教育学科（见附件IV）。《国际教育标准分类法》2011版对1997版中的教育 等级分类有所修订, 并引入一个以公认的教育资格证书为基础划分受教育程度的相关分类方法。

4. 按《国际教育标准分类法》汇编的资料, 能用于收集决策者与国际教育统计其它使用者所感兴趣的 教育的许多不同方面的统计数字，这些方面包括注册人数和到课率、教育中所投入的人力或资金、 以及国民的受教育程度。

5. 使用《国际教育标准分类法》有助于把根据国家概念与定义所汇编的关于教育参加者、提供者和资 助者的详细国家教育统计数字, 转换成为能在国际上进行对比和解释的综合类别。

6. 根据《国际教育标准分类法》收集教育统计数据可以不同的数据来源为基础, 如行政登记部门、个 人和住户调查、以及宏观经济综合的统计数据等。《国际教育标准分类法》2011版有关统计数据来 源的实施指导将列入操作手册和其它培训材料中（见第8章）。

7. 《国际教育标准分类法》2011版基于以下三要素：i）国际公认的概念和定义; ii）分类系统; 和 iii）《国际教育标准分类法》对世界各国教育课程和相关资格证书进行的图谱分析。

8. 《国际教育标准分类法》图谱分析是整理关于国家教育系统、其课程和相关资格证书的资讯的一个 重要工具, 以确保《国际教育标准分类法》等级资料的可比性, 并支持为国际统计目的对其所进行 的解释。

9. 《国际教育标准分类法》图谱分析确保一个透明过程, 通过把分类标准与教育课程及其相关资格证 书的特性连接, 将国家教育课程及其相关资格证书编码为可比较的类别, 供国际统计工作使用。 
10. 《国际教育标准分类法》中的基本分类单位是国家和国家以下的教育课程和相关的公认教育资格证书。

11. 在《国际教育标准分类法》中，教育课程系指为在一段持续的时期内达到预定的学习目标或完成一 组具体的教育任务而设计和组织的一套连贯或序列的教育活动或交流。目标包括提高个人、民事、 社会和 / 或就业方面的知识、技艺和能力水平。学习目标, 一般与为学习深造和 / 或从事某个职 业、行业或某种职业或行业做准备相关连，但也可能与个人的发展或闲暇娱乐相关。教育课程的共 同特征是，在达到学习目的或完成教育任务时，成功完成是经过证明的。

以上定义中的几个关键词应理解如下:

12. 教育活动：有意识的活动，涉及某种形式的交流，旨在引发学习。

13. 交流：两个或更多的人之间、或无机媒介与人之间的一种关系, 涉及信息传输（讯息、观念、知 识、战略等）。交流可为言语的或非言语的、直接 / 面对面的或间接 / 远距离的, 并涉及各种各 样的途径及媒介。

14. 学习: 个人通过经历、实践、研究或授课而在信息、知识、理解、态度、价值、技艺、能力或者行 为方面的获取或改变。

15. 有组织的：按一定的形式或序列计划，带有明确或隐含的目标。这牵涉到一个能便利学习环境的提 供者（人或机构），和一种组织交流的授课方法。授课一般牵涉某个以引发学习为目的而开展交流 和传授知识和技能的教师或教练。授课的媒介也可以是间接的，例如通过无线电、电视、计算机软 件、电影、录音、互联网或其它通信技术。

16. 持续的：学习经历带有持续时间和连续性的成分。

17. 教育课程在国家层面可能有严格的界定和规定。《国际教育标准分类法》对教育课程的定义照顾到 不同国家出现的多种可能情况，以便达到在国际层面可比较的目的。

18. 教育课程中的教育活动还可以被分组为各国所说的 “课”、“单元”、“单位” 和 / 或 “课目”。 《国际教育标准分类法》的“课”在意义上等同于 “单元”、“单位”和 / 或 “课目”。教育课程 可包含一些通常不被视为课的重要内容, 诸如游戏教学活动、实习期、研究课题、和准备论著等。 
19. 教育课程的分类决定对教育系统统计资料的报告, 例如, 注册人数、入学人数、教师和其它人力和 财务资源。教育课程的统计能就投入（系统的入学数）, 过程（参加）和产出（资格证书）之间的 联系提供信息。

20. 《国际教育标准分类法》的教育资格证书是正式确认, 通常以文件的形式证明成功完成一个教育课 程或课程的某个阶段。获得资格证书的方式有：i）成功完成一个完整教育课程；ii）成功完成一个 教育课程的某个阶段（中间资格证书）；或iii）对所掌握知识、技艺和能力的验证，而不考虑是否 参加教育课程。一个学生达到特定的学习目标时通常被认定为成功完成一个课程。成功完成单独的 课（例如单元或课目）而获得的单独学分在《国际教育标准分类法》中不视为资格证书。在这类情 况下, 足够的学分数或课目在持续时间上等同于一个完整课程和 / 或覆盖一个完整课程的课表, 代 表一个资格证书。

21. 《国际教育标准分类法》2011版将与教育课程相对应的公认资格证书考虑为一个相关的分类单 位。在《国际教育标准分类法》中，“资格证书”一词是“资质证明”的同义词。其它词语 如“证书”、“学位”、“毕业证书”，是资格证书的种类，在《国际教育标准分类法》中可看 作为同义词。将有关国家教育当局正式认可的资格证书进行分类是受教育程度统计的基础。

22. 《国际教育标准分类法》中教育课程先进行分类, 资格证书然后进行分类。《国际教育标准分类 法》图谱分析是一个显示教育课程与资格证书之间联系的工具。通常一个教育课程产生一个资格证 书。但是, 在某些情况下, 几个课程可产生同一资格证书, 一个课程可产生若干不同的资格证书。

23. 对非正规教育或非正式学习的（先前）学习的认可过去十年在许多国家越来越普遍。《国际教育标 准分类法》2011版明确地容许对通过证明所学得的技艺、知识和能力, 与成功完成正规教育课程相 类似，并得到一个正式的资格证书承认的资格证书进行分类。

24. 《国际教育标准分类法》2011版不能用来直接评估个人的能力, 因为教育课程或资格证书与实际的 教育成果之间没有直接的关系。个人参加或成功完成的教育课程, 最多只是完成时技艺、知识和能 力的大致反映。

25. 国家和地区的资格证书框架可以是区分与课程和资格证书相关的知识、技艺和能力的一个有用的工 具。很多国家都存在这样的框架, 以从教育成果的角度来描述人口的能力和技艺的等级。建议各国 将其国家或地区的资格证书框架，如果存在的话，与《国际教育标准分类法》之间的连接做得清晰 易懂。 


\section{第三章 跨等级课程、序列课程和单元式课程}

26. 在按照《国际教育标准分类法》等级对国家教育课程进行分类时, 国家课程间的转变点和劳务市场 的切入点并不总是与《国际教育标准分类法》等级之间的转变点相对应。有三种这样的情况可以鉴 定：i）跨《国际教育标准分类法》两个或两个以上等级的课程；ii）两个或两个以上的序列课程一 起构成一个《国际教育标准分类法》等级；和iii）课程用单元或课目提供, 没有明确界定的顺序。

27. 国家教育课程的持续时间如果超过《国际教育标准分类法》等级所规定的标准（见第 70 段和第 71 段），则视为跨一个以上的等级。因此，有必要鉴定在按照此标准确定课程进程内从一个《国际 教育标准分类法》等级至下一个等级的一个或多个转变点。例如, 当一个国家小学教育课程为 8 年或更长时, 最后的几个年级应分类为《国际教育标准分类法》2级（例如, 首先的六个年级分 类为《国际教育标准分类法》1级, 最后的两个年级为《国际教育标准分类法》2级）。

28. 为了对跨一个以上《国际教育标准分类法》等级的课程进行分类, 课程内的现有转变点, 如阶段或 中间资格证书等, 应用来将课程的相关年级划归相应的《国际教育标准分类法》等级。如果没有此 种转变点，《国际教育标准分类法》等级的典型累计持续时间（见第71段）可指导如何鉴定《国际 教育标准分类法》等级之间的界线。关于《国际教育标准分类法》等级的进一步说明见第9章。

29. 跨一个以上《国际教育标准分类法》等级的课程通常在较低《国际教育标准分类法》等级结束时不 提供资格证书。在这种情况下，其它标准可用来界定等级完成，例如，完整地参加划为《国际教育 标准分类法》较低等级的最后年级, 或获准进入划为《国际教育标准分类法》更高等级的年级。

30. 报告跨《国际教育标准分类法》等级的课程要有一些特别的考虑。注册人数按照《国际教育标准分 类法》等级报告, 通常使用按年级或年份分的统计数据。财务和人力资源也可按照等级（或等级 组, 例如高等教育) 估算。当报告一个《国际教育标准分类法》等级的新入学或毕业生人数时, 该 课程所跨的所有等级是分别考虑的。

31. 为了遵从《国际教育标准分类法》等级的持续时间标准（见第70段和第71段），可能有必要把两 个或多个序列课程划分在同一个《国际教育标准分类法》等级中，如果它们合在一起符合最短持续 时间标准，而单个课程持续时间达不到此标准。在这种情况下，教育系统中从第一个到第二个或后 面的课程的进级在报告给定《国际教育标准分类法》等级毕业生数据中不予反映, 但任何公认的中 间资格证书可以在子类别中报告：i）《国际教育标准分类法》2级和3级中的 “部分等级完成” 或 ii）《国际教育标准分类法》其它等级中的“无等级完成”（见第60段）。如果教育系统中4个而不 是2个或3个序列课程构成《国际教育标准分类法》1至3级时, 就会出现这种情况。 
32. 构成一个《国际教育标准分类法》等级的两个或多个序列课程在报告时需要特别的考虑。这一等级 所有课程的注册人数应合在一起。入学人数的数据仅考虑那些进入该《国际教育标准分类法》等级 中第一个课程的人数, 而毕业生人数的数据仅考虑完成该等级最后序列课程的人数。就受教育程度 而言, 只有公认成功完成该序列的最后课程, 才算作等级完成。公认成功完成该《国际教育标准分 类法》等级中的早期课程则在子类别“部分等级完成”或 “无等级完成” 中报告（见第60段）。

33. 单元式课程允许学生组合不同的课或单元, 灵活地安排教育内容。单元的组合可视为一个教育课 程，如果符合《国际教育标准分类法》对于教育课程的定义的话（见第11段）。

34. 构成一个教育课程各单元的所有参加者, 均视为在该课程注册, 即使他们仅仅参加某些单元, 而这 些单元本身也许比所给定《国际教育标准分类法》等级的典型持续时间短。单元式课程在成功完成 该教育课程所要求的单元数和种类时视为成功完成。 


\section{《国际教育标准分类法》中教育的范围}

35. 《国际教育标准分类法》2011版涵盖给一个人一生中的任何阶段所提供的正规和非正规教育课程。 相关国家教育当局公认的资格证书，无论是怎样获得的（例如通过成功完成一个正规教育课程或通 过一个非正规教育课程或非正式的学习活动），被用来衡量受教育程度。《国际教育标准分类法》 不覆盖非正式的、顺带的或无约束的学习，也不覆盖那些不被公认的资格证书。正规或非正规教育 包括在一国环境中所设计的各种教育课程，如初期教育、常规教育、二次机会课程、扫盲课程、成 人教育、继续教育、开放和远程教育、实习、技艺或职业教育、培训或特殊需要教育。

36. 正规教育系指通过公共组织和公认的私人团体进行的有制度、有目的、有计划的教育, 它们的总和 构成一个国家的正规教育系统。正规教育课程因此由相关的国家教育当局或等同机构，例如任何 其它与国家或地方的教育当局合作的机构，作如此公认。正规教育主要由初期教育构成（见第37 段）。职业教育、特殊需要教育和部分成人教育通常被公认为正规教育系统的一部分。来自正规教 育的资格证书按定义公认，因此属于《国际教育标准分类法》的范围。有制度的教育是指由一个组 织专门为教育和学习目的而设计的有结构的教育安排，例如师生关系和 / 或互动等。

37. 正规教育一般在教育机构进行，该机构的设计是用来在具有连续教育路径的体系中为学生提供全日 制教育。这被称为初期教育，其定义是个人首次进入劳务市场之前所受的正规教育，即通常处于全 日制教育。

38. 正规教育还包括采用面向所有年龄组人员，课程内容和资格证书与初期教育相同的教育。部分在工 作场所开办的课程，如果所颁发的资格证书获得国家教育当局（或相当的机构）公认，也可视为正 规教育。这些课程通常由教育机构和雇佣方合作提供（例如实习）。

39. 非正规教育, 和正规教育一样（而并非非正式的、顺带的或无约束的学习）, 系指通过教育提供者 进行的有制度、有目的、有计划的教育。非正规教育的突出特点是在个人一生学习的过程中对正规 教育的追加、替代和 / 或补充。其提供的目的通常是为了保障所有人受教育的权利。它顾及各种年 龄的人但无须采用连续的路径结构; 可能持续时间短和 / 或强度低; 通常以短课程、研讨班或讲座 的形式提供。非正规教育多数提供不被相关国家或地方教育当局公认为正式或等同于正式资格证书 的资格证书，或者根本就没有资格证书。然而，通过单独参加特定非正规教育课程也可获得正式公 认资格证书：这通常出现在非正规课程完成在别的环境中获得的技能的情况。

40. 根据各国的情况, 非正规教育可以包括有助于成人和青年扫盲课程、失学儿童的教育、以及有关生 活技能、工作技能和社会或文化发展的课程。它可包括在工作场所为提高或调整现有资格证书和 技能而进行的培训，为失业或待业人员进行的培训，以及某些情况下正规教育和培训的替代教育路 径。非正规教育还可包括为追求个人发展因而不一定是与工作相关的学习活动。 
41. 成功完成一个非正规教育课程和 / 或非正规教育资格证书通常不通向更高等级的教育, 除非经过正 规教育系统适当确认并获得相关国家或国家以下教育当局（或等同机构）的公认。

42. 《国际教育标准分类法》2011版中正规与非正规教育的统计目的有明显的差别。《国际教育标准分 类法》2011版建议采用内容和 / 或产生的资格证书等同的标准对非正规教育课程进行分类。附件V 提供了有关非正规教育课程分类的进一步信息。目前, 有关教育的国际数据收集活动（图谱分析、 调查、人口普查等) 主要集中在正规教育。

43. 非正式学习不属于《国际教育标准分类法》用于评估教育参与的范围, 尽管在确定受教育程度等级 时通过非正式学习所获得的公认资格证书被考虑在内。非正式学习系指有目的的或有意的但不是有 制度的学习形式。因此, 它缺乏像正规或非正规教育那样有组织和有结构。非正式学习可包括在家 庭、工作场所、地方社区中心、和日常生活中基于自我督导、家庭督导或社会督导的学习活动。像 正规和非正规教育一样, 非正式学习可与顺带学习或无约束学习区别开来。

44. 《国际教育标准分类法》不包括顺带学习或无约束学习, 如各种未经组织过的学习或所涉及的交流 并不是为了引起学习。顺带学习或无约束学习可能是日常活动的副产品抑或是没按照有意的教育或 学习活动而设计的事件或交流的附带结果。例子可包括会议过程中, 收听电台节目或观看并不是按 教育课程设计的电视节目而发生的学习。 


\section{第五章 交叉分类的变量}

45. 《国际教育标准分类法》的主要交叉变量是教育等级和学科（见附件 IV 关于教育学科）。在《国际 教育标准分类法》各个等级之内, 课程和资格证书按补充标准进一步分类。这些包括:

- 课程定向;

- 完成《国际教育标准分类法》等级;

・通向更高《国际教育标准分类法》等级; 以及

- 在国家学位和资格证书结构中的定位。

并非所有的补充标准适用于所有的等级。此外，《国际教育标准分类法》0级按课程类型和目标年龄 组作进一步细分。由这些补充标准所提供的类别和子类别允许更详细地收集和报告跨国可比较数据。

46. 在《国际教育标准分类法》描述的这些之外，课程和资格证书的其它描述性特点和特性包括教育提 供者、教育场景或地点、机构环境、提供教育的模式、参加者的类型或参加的模式。尽管没有明确 地作为补充标准列入 《国际教育标准分类法》，但是，这些特点在区分许多国家的课程的性质和确 定数据收集的范围时发挥一个重要的作用。

\section{等级}

47. 教育 “等级” 这个概念用一套有序的集来表示, 根据与学习经历的进阶以及一个课程应予传授的知 识、技艺和能力的关系, 将教育课程分组。《国际教育标准分类法》等级反映一个教育课程内容从 基础到综合的复杂程度和专业程度。

48. 教育等级因此是以假定教育课程可以归组于一套有序的类别序列为基础的一个构造。这些类别代表 教育进阶中反映教育内容复杂程度的主要阶段。课程越复杂，教育等级就越高。

49. 将教育课程分为等级进阶是为了反映教育系统中可得到的全部教育路径。大多数教育系统提供数种 从《国际教育标准分类法》0/1级至8级的可能路径（见附件|中的图2）。个人可能以许多方式安排 自己的教育路径, 因为教育系统提供多种分支途径、可供选择的课程序列和第二次机会。但是, 个 人很少通过所有可能等级。

50. 按等级划分教育课程是为了反映它们的内容。但是, 课目种类太多, 涉及太多方面, 太复杂, 无法 用一致的方式直接评估和对比各教育系统课程的内容。由于没有直接的措施来对教育内容进行分 类, 《国际教育标准分类法》采用辅助标准帮助将一个特定的教育课程划入适当的教育等级。这些 辅助标准有时在每一个《国际教育标准分类法》等级是特定的, 因此将在各自章节中加以解释。每 级关于持续时间和累积持续时间的通用标准将在本章的最后加以概括。 
51. 这些辅助标准由主要和次要标准组成。主要标准说明各个《国际教育标准分类法》等级教育课程的 必要特点。次要标准说明这一等级中许多但不是所有的教育课程所共有的特点（见第 9章）。

52. 对课程进行分类的最重要的标准是其教育内容的复杂程度和专业程度, 以及这一内容如何反映在 辅助标准中。机构环境不应当用来替代教育内容作为一项分类标准。例如, 《国际教育标准分类 法》4级课程可在一般提供《国际教育标准分类法》5级或6级课程的机构进行。

定向

53. 课程定向在《国际教育标准分类法》2 到5级是有区分的, 在 6 到 8 级中有可能用到。定向有 2 个类 别：普通和职业教育。在高等教育级中，术语 “学术” 和 “专业” 分别用来代替 “普通” 和 “职 业”。《国际教育标准分类法》2011版还没有更精确地在更高的《国际教育标准分类法》等级中定 义学术和专业, 但是为将来根据诸如教育的学科来区分学术和专业的定向提供了可能。在研究出学 术和专业的定义之前, 《国际教育标准分类法》5级采用普通和职业教育的定义。

54. 职业教育系指主要为学习者掌握在某一特定的职业或行业或某类职业或行业从业所需特有的知 识、技艺和能力而设计的教育课程。这样的课程可能有基于工作的成分（例如实习, 双轨制教育 课程）。成功完成这类课程, 授予认可的与劳务市场相关的职业资格证书, 相关国家主管当局 和 / 或劳务市场承认其职业定向。

55. 普通教育系指为发展学习者的普通知识、技艺和能力以及读写和计算技能而设计的教育课程, 通常 为参加者进入《国际教育标准分类法》同级或更高级阶段的教育课程做准备, 并为终身学习奠定基 础。这些课程通常是在学校或学院开设的。普通教育包括教育课程为参加者进入职业教育做准备, 但是不为从事某一特定的职业或行业或某类职业或行业做准备, 也不直接授予与劳务市场相关的资 格证书。

\section{完成和通向更高教育等级}

56. 成功完成一个教育课程的要求, 例如达到学习目标, 一般会在课程详细说明中规定。通常包括:

- 到课率要求（注册并正常上课, 直至课程的最后一年）; 和 / 或

- 表明掌握了预期的知识、技艺和能力

57. 对构成一个教育课程的学习目标的知识、技艺和能力的掌握, 其确认一般是:

- 通过（即成功完成）基于课程的最终考试或一系列考试;

- 积累规定的学分数; 或

- 成功通过对所获得的知识、技艺和能力的正式评估。

在正规教育中, 成功完成通常获得相关国家教育当局公认的资格证书。 
58. 《国际教育标准分类法》1和2级（偶尔《国际教育标准分类法》3或4级）教育课程并不总是以资格 证书结束。在这些情况下, 其它标准, 而不是资格证书, 应该用来确定成功完成; 例如参加该课程 的最后一整年或准予通向更高等级的教育。

59. 当所获得的资格证书是为了给予直接通向一个更高《国际教育标准分类法》等级而设计时, 成功完 成《国际教育标准分类法》1至3级课程总是视作等级完成。在《国际教育标准分类法》3级的情况 中, “更高《国际教育标准分类法》等级” 意指《国际教育标准分类法》5、6或7级。资格证书视 为准予通向更高《国际教育标准分类法》等级, 即使该准予仅限于通向《国际教育标准分类法》更 高等级的一些课程。成功完成分类为《国际教育标准分类法》4至8级中的课程视为等级完成。但 是, 在受教育程度方面, 在完成课程之前获得的公认资格证书（即从成功完成课程的一个阶段产生 的公认中间资格证书）划为较低的《国际教育标准分类法》等级。当所得的资格证书不直接通向更 高的《国际教育标准分类法》等级, 成功完成课程可视为等级完成（无通向）或无等级完成。仅在 《国际教育标准分类法》2级和3级, 不通向更高《国际教育标准分类法》等级的资格证书, 可视为 等级完成（无通向）, 部分等级完成或无等级完成。

60. 《国际教育标准分类法》2至3级中的教育课程和相应的资格证书划分为4个子类别：

i) 无等级完成（因此不直接通向一个更高《国际教育标准分类法》等级一一在《国际教育标准分类 法》3级的情况下即5、6或7级）；

ii) 部分等级完成但不直接通向一个更高《国际教育标准分类法》等级；

iii) 等级完成但不直接通向 一个更高《国际教育标准分类法》等级;

iv) 等级完成并直接通向一个更高《国际教育标准分类法》等级（在《国际教育标准分类法》3级的 情况下即在5、6或7级的第一个高等课程）。

61. 成功完成不通向更高《国际教育标准分类法》等级 (在《国际教育标准分类法》3级的情况中 指5、6或7级) 的《国际教育标准分类法》2或3级课程视为等级完成或部分等级完成, 如果该 课程满足以下标准：i）该课程在所处《国际教育标准分类法》等级有至少2年学习的持续时间； 和ii）《国际教育标准分类法》2级课程的累计持续时间从《国际教育标准分类法》1级开始至少 8年, 《国际教育标准分类法》3级课程至少11年。成功完成这两个《国际教育标准分类法》等级 的短线课程视为成功完成该课程本身。就受教育程度而言, 成功完成短线课程所获得的任何公认 资格证书划入比该课程本身低一级的《国际教育标准分类法》等级。 
62. 以下课程:

a） 不满足内容、最少持续时间和 / 或累计持续时间标准，划入类别1（无等级完成）。

b) 满足内容、最少持续时间和累计持续时间标准，是同一《国际教育标准分类法》等级的序列 课程的一部分（但不是该序列的最后课程）, 因而不直接通向更高《国际教育标准分类法》等 级, 划入类别2（部分等级完成）。

c) 满足内容、最少持续时间和累计持续时间标准并且为终端课程, 划入类别3 (等级完成但不直 接通向）。这些课程通常直接授予与劳务市场有关的资格证书。

d）只通向《国际教育标准分类法》4级课程的《国际教育标准分类法》3级课程也划入类别3 (等 级完成但不直接通向）。

e） 直接通向在《国际教育标准分类法》5级, 6级或7级的高等教育划入类别4（等级完成并直接 通向）。

63. 针对特定参加者群体（成人或有特殊需要的个人）的课程可能比所在《国际教育标准分类法》等级 的常规教育同样课程的时间短或长。但是, 成功完成课程应只视为等级完成, 如果所获资格证书表 明掌握了与同级常规教育课程同等水平的知识、技艺和能力。

64. 参加一个课程但没有成功完成, 不符合等级完成或部分等级完成的条件, 除《国际教育标准分类 法》0和1级之外, 在确定受教育程度等级时不加考虑。因此, 没有成功完成一个给定课程的个人的 受教育程度等级是其进入该课程之前所达到的最高等级。

65. 尽管等级完成的标准应用于成功完成因而仅直接适用于个人, 但是教育课程作为一个整体是根据它 们旨在准备的最高可能的资格证书来分类，即使某些参加者不会获得这个资格证书。

\section{在国家学位和资格证书结构中的定位}

66. 《国际教育标准分类法》6 和7级课程根据其在国家学位和资格证书结构中的定位进行区分。有必要 考虑国家课程和资格证书的顺序, 以便正确地统计高等教育（或其构成等级）的初次入学和毕业生 人数。对一个课程的定位是根据国家高等教育体系中学位和资格证书的顺序来进行的。

67. 不要求先完成另一个6级课程作为入学条件的《国际教育标准分类法》6级课程, 归类为第一学位课 程。所有其它《国际教育标准分类法》6级课程归类为第二或其它学位课程。

68. 不要求先完成一个6级课程作为入学条件的《国际教育标准分类法》7级课程, 归类为第一学位课 程。其它7级课程也许要求事先完成一个6级课程或另一个7级课程。这些课程在《国际教育标准分 类法》中分别归类, 以便更好地鉴定《国际教育标准分类法》7级的初次入学和毕业生人数。 


\section{持续时间和累计持续时间标准}

69. 鉴于其在课程等级分类和鉴定等级完成中的重要性, 这里对持续时间标准进行详细说明。其余标准 在第9章说明。

70. 《国际教育标准分类法》各等级的如下课程持续时间范围，用作对正规教育课程分类的标准：

- 《国际教育标准分类法》0级：无持续时间标准, 但列入的话, 课程须具备至少等同于每天2小时 和一年100天的教育活动;

- 《国际教育标准分类法》1级：持续时间通常为4至7年不等。最常见的持续时间为 6 年;

- 《国际教育标准分类法》2级：持续时间通常为2至5年不等。最常见的持续时间为3年;

- 《国际教育标准分类法》3级：持续时间通常为2至5年不等。最常见的持续时间为3年;

- 《国际教育标准分类法》4级：持续时间通常为6个月至2或3年不等;

- 《国际教育标准分类法》5级：持续时间为2至3年不等; 以及

- 《国际教育标准分类法》8级：持续时间至少为3年。

《国际教育标准分类法》6级和7级的典型持续时间通过参照相应等级课程的持续时间更容易描述， 因为《国际教育标准分类法》的持续时间取决于不同国家在这些等级所提供的课程顺序。

- 《国际教育标准分类法》6级：学士或等同水平课程的持续时间，如接《国际教育标准分类法》 3 级, 通常为3至4年或更长不等; 如接另一个《国际教育标准分类法》6级课程, 则 1 至2年不等;

- 《国际教育标准分类法》7级: 硕士或等同水平课程的持续时间, 如接《国际教育标准分类法》 6 级，通常为1至4年不等; 如直接接《国际教育标准分类法》3级，则5至7年不等。

71. 《国际教育标准分类法》使用如下累计持续时间范围, 作为对正规教育课程分类的标准：

-《国际教育标准分类法》1+2级：典型的累计持续时间为9年，但可在8至11年之间；

- 《国际教育标准分类法》1+2+3级：典型的累计持续时间为12年, 但可在11至13年之间。高等教 育入学通常要求在《国际教育标准分类法》1至3级至少有11年的教育。

72. 在非全日制或单元课程中应用持续时间标准时, 理论课程持续时间应按全日制等同来衡量。 
73. 虽然《国际教育标准分类法》的主要目标是促进收集和使用可比较的教育数据, 但是, 要认识到各 国的情况可能不同, 在确定等级的持续时间时需要有灵活性。因此, 第70段和第71段提供了持续时 间年数范围。在对课程进行分类时, 最好采用最常见或典型的持续时间。

74. 第70段和第71段中所述的等级持续时间和累计持续时间是作为一个指南。但是, 机构转变点也可用 作将一个课程归类到一个《国际教育标准分类法》等级的标准。选定与国际类别相应的国家转变点 主要考虑教育课程的内容, 而不是 (累计) 持续时间。 


\section{第六章 数据的类型}

75. 《国际教育标准分类法》总体上是用于统计参加者人数、入学人数、毕业生人数和受教育程度。 《国际教育标准分类法》不是一个关于数据收集的指南, 也不详细规定数据收集的覆盖面或者怎 样让统计单位运作。但是，对于不同类型的统计，以下原则在应用《国际教育标准分类法》时加 以考虑。

\section{注册人数、到课率和入学人数}

76. 为了准确地衡量注册人数、到课率和入学人数, 学生必须分配到每一个《国际教育标准分类法》等 级、类别和子类别。组织环境不应作为收集统计数据的依据。同一机构中处于不同《国际教育标准 分类法》等级和类别的学生人数需要分别报告, 必要时可通过估算。跨《国际教育标准分类法》不 同等级教育课程的学生, 应采用按年级或阶段分的统计数据报告。

77. 学生按照课程的特点而不是学生个人的特点划入《国际教育标准分类法》的等级和类别。例如, 学 前教育类别面向3岁和3岁以上的儿童, 但在这一课程注册的年龄较小的儿童也应在这一类别中报 告。同样，使用关于通向更高等级的类别的统计应基于课程的设计而不是单个学生的路径。

78. 《国际教育标准分类法》等级的新入学者必须与进入教育课程但未进入新等级（即那些以前进入 《国际教育标准分类法》等级的学员）的入学者区分开来。同一等级已进行了一个课程的教育课 程入学者在报告这一等级的入学人数时不包括在内。对于跨两个《国际教育标准分类法》等级的 的课程而言, 进入较高等级一年级的参加者需视为一个《国际教育标准分类法》等级的入学人 数，尽管从国家的角度而言，他们将在同一课程内继续接受教育。

\section{毕业生人数}

79. 一个《国际教育标准分类法》等级的毕业生人数包括那些进入并成功地完成一个归类为 “等级完 成” 的教育课程的学员。原则上, 只有那些成功完成所注册的整个等级或一组等级的学生（例如高 等教育中的首次结业）才计入，以维持入学人数、学生注册人数和毕业生人数之间的衔接。仅通过 成功完成《国际教育标准分类法》等级的一个阶段而获得同样或等同资格证书的学生, 不应计入毕 业生人数。

80. 在任何一个给定的《国际教育标准分类法》等级, 毕业生人数只应在成功完成最高课程的等级时统 计一次。这与高级中等教育和高等教育尤其相关, 因为在同一个《国际教育标准分类法》等级内序 列课程可能先后相接。毕业生人数的精确测定意味着跟踪学生个人从入学至完成整个等级（或一组 等级) 的情况。这在实际中不切实可行, 常常有必要开发估计方法来推知毕业生人数数据, 例如通 过以样本为基础的届数跟踪调查。 


\section{受教育程度}

81. 个人的受教育程度系指个人完成的最高《国际教育标准分类法》等级。为了方便操作, 受教育程度 通常是根据公认资格证书证明成功完成的最高教育课程来评定的。公认的中间资格证书归类于比该 课程本身低的等级。

82. 一个教育课程通常视为是成功的完成, 如果学生到校上课, 完成一个正规教育课程, 并取得一个公 认的资格证书（见第56段至第58段）。

83. 相关国家教育当局可能认定等同于正规教育资格的这类证书, 即通过非正规教育课程或对通过非正 式学习得到技能经验证所得到的资格证书。《国际教育标准分类法》所定义的受教育程度概念也考 虑到这些资格证书。非正规教育或技能验证所得的资格证书不被公认等同于正规资格证书, 则不在 《国际教育标准分类法》的涵盖范围（见第35段）。

84. 《国际教育标准分类法》中受教育程度的定义应该与其它关于个人教育成绩的概念区分开来。个人 成绩可包括参加过但未成功完成的教育等级, 或通过标准化的测试或学校教育年数确定的个人实际 知识、技艺和能力（即读写和计算能力的等级）。

85. 仅参加一个教育课程的部分或不满足完成要求（例如没通过最后考试）的个人不够称成功完成课 程。他们应该按照成功完成的最高《国际教育标准分类法》等级（即进入没有成功完成的课程之 前）进行分类。

86. 在受教育程度分类方面, 0级有着与教育课程分类不同的含义: 它意味着没有成功完成《国际教 育标准分类法》1级。这包括那些从未上过一个教育课程, 受过一些早期儿童教育, 或受过一些 初等教育但未成功完成《国际教育标准分类法》1级的个人。本受教育程度等级考虑了几个子类 别（见表4）。

87. 受教育程度分类可依据所完成（或部分完成）的《国际教育标准分类法》等级、课程定向和通向更 高《国际教育标准分类法》等级。如果一个人不止一次成功完成同一《国际教育标准分类法》等级 （例如参加供平行选修的两个不同课程），最近获得的资格证书的特点应予报告。

88. 受教育程度统计涵盖所有年龄组的个人, 其中某些或许多人完成了不同于目前提供的教育课程或者 资格证书。为了使指标具有跨时间和教育届数之间的可比性, 受教育程度应以在成功完成时教育课 程和公认资格证书的特点为基础进行分类。 


\section{第七章 编码系统}

89. 《国际教育标准分类法》的分类由并行的教育课程等级 (《国际教育标准分类法》教育课程或 ISCED-P) 和受教育程度等级（《国际教育标准分类法》受教育程度或ISCED-A）两个编码系统构 成。在这两个编码系统中, 9 个不同的等级有所鉴定。在每一个等级中, 补充标准用来鉴定, 如果 适用的话，进一步分类和子分类。三数字编码系统用来对教育课程和受教育程度编码。

\section{表1.《国际教育标准分类法》等级编码（第一个数字）}

\begin{tabular}{|c|l|c|l|}
\hline \multicolumn{2}{|c|}{ 《国际教育标准分缕法》教育课程 (ISCED-P) } & \multicolumn{3}{|c|}{ 《国际教育标准分哭法》受教育程度 (ISCED-A) } \\
\hline 0 & 早期儿童教育 & 0 & 低于初等教育 \\
\hline 1 & 初等教育 & 1 & 初等教育 \\
\hline 2 & 初级中等教育 & 2 & 初级中等教育 \\
\hline 3 & 高级中等教育 & 3 & 高级中等教育 \\
\hline 4 & 中等后非高等教育 & 4 & 中等后非高等教育 \\
\hline 5 & 短线高等教育 & 5 & 短线高等教育 \\
\hline 6 & 学士或等同水平 & 6 & 学士或等同水平 \\
\hline 7 & 硕士或等同水平 & 7 & 硕士或等同水平 \\
\hline 8 & 博士或等同水平 & 8 & 博士或等同水平 \\
\hline 9 & 别处未分类 & 9 & 别处未分类 \\
\hline
\end{tabular}

\section{表2.《国际教育标准分类法》类别编码（第二个数字）1}

\begin{tabular}{|c|c|c|c|}
\hline \multicolumn{2}{|r|}{ 《国际教育标准分类法》教育课程 (ISCED-P) } & \multicolumn{2}{|r|}{ 《国际教育标准分类法》受教育程度 (ISCED-A) } \\
\hline 0 & 未进一步定义 & 0 & 未进一步定义 \\
\hline 1 & 早期儿童教育开发 & 1 & 从未上过一个教育课程 \\
\hline 2 & 学前教育 & 2 & 某些早期儿童教育 \\
\hline 3 & 未使用 & 3 & 某些初等教育（未完成《国际教育标准分类法》1级） \\
\hline 4 & 普通 / 学术 & 4 & 普通 / 学术 \\
\hline 5 & 职业 / 专业 & 5 & 职业 / 专业 \\
\hline 6 & 定向未定 ${ }^{2}$ & 6 & 定向未定 ${ }^{3}$ \\
\hline 7 & 未使用 & 7 & 未使用 \\
\hline 8 & 未使用 & 8 & 未使用 \\
\hline 9 & 别处未分类 & 9 & 别处未分类 \\
\hline \multicolumn{4}{|c|}{$\begin{array}{l}\text { 1. 课程: 课程类型（ISCED-P 0级）、定向（ISCED-P 2至8级）、未进一步定义（ISCED-P 1级） } \\
\text { 受教育程度：参加（ISCED-A 0级）、定向（ISCED-A 2至5级）、未进一步分类（ISECD-A 1级和6至8级） } \\
\text { 2. 用于ISCED-P 6至8级 } \\
\text { 3. 用于ISCED-A 5至8级 }\end{array}$} \\
\hline
\end{tabular}




\section{表3.《国际教育标准分类法》子类别编码（第三个数字）1}

\begin{tabular}{|c|c|c|c|}
\hline \multicolumn{2}{|r|}{ 《国际教育标准分类法》教育课程（ISCED-P） } & \multicolumn{2}{|r|}{ 《国际教育标准分类法》受教育程度 (ISCED-A) } \\
\hline 0 & 末进一步定义 & 0 & 未进一步定义 ${ }^{2}$ \\
\hline 1 & $\begin{array}{l}\text { 公认成功完成课程, 不够《国际教育标准分类法》等级完成 } \\
\text { 或部分完成 (因此不直接通向《国际教育标准分类法》更高 } \\
\text { 等级课程) }\end{array}$ & 1 & 未使用 \\
\hline 2 & $\begin{array}{l}\text { 公认成功完成课程, 足够《国际教育标准分类法》等级部分 } \\
\text { 完成但不直接通向《国际教育标准分类法》更高等级课程 }\end{array}$ & 2 & $\begin{array}{l}\text { 部分等级完成, 不直接通向《国际教育标准分类 } \\
\text { 法》更高等级课程 }\end{array}$ \\
\hline 3 & $\begin{array}{l}\text { 公认成功完成课程, 足够《国际教育标准分类法》等级完成 } \\
\text { 但不直接通向《国际教育标准分类法》更高等级课程 }{ }^{3}\end{array}$ & 3 & $\begin{array}{l}\text { 等级完成, 不直接通向《国际教育标准分类法》 } \\
\text { 更高等级课程 }\end{array}$ \\
\hline 4 & $\begin{array}{l}\text { 公认成功完成课程, 足够《国际教育标准分类法》等级完成 } \\
\text { 并直接通向《国际教育标准分类法》更高等级课程 }, 4\end{array}$ & 4 & $\begin{array}{l}\text { 等级完成, 直接通向《国际教育标准分类法》更 } \\
\text { 高等级课程 }{ }^{3,5}\end{array}$ \\
\hline 5 & 第一学位 - 学士或等同水平（3-4年） & 5 & 未使用 \\
\hline 6 & 长线第一学位课程 - 学士或硕士、或等同水平 & 6 & 未使用 \\
\hline 7 & 第二或其它学位课程, 在完成一个学士或等同课程后 & 7 & 未使用 \\
\hline 8 & 第二或其它学位课程, 在完成一个硕士或等同课程后 & 8 & 未使用 \\
\hline 9 & 别处未分类 & 9 & 别处未分类 \\
\hline \multicolumn{4}{|c|}{$\begin{array}{l}\text { 2. ISCED-A 1级和5至7级中, 包括成功完成《国际教育标准分类法》更高级课程或课程的一个阶段, 不够等级完成或部分等级 } \\
\text { 完成。 } \\
\text { 3. 在《国际教育标准分类法》3级的情况下, 《国际教育标准分类法》更高等级指的是ISCED-P } 5 \text { 至7级课程。 } \\
\text { 4. 在《国际教育标准分类法》5和8级的情况下, 全部 (所有) 课程归类于类型 } 4 \text {, 无论它们是否通向《国际教育标准分类法》 } \\
\text { 更高等级。 } \\
\text { 5. ISCED-A 2至4级中, 包括成功完成《国际教育标准分类法》更高级课程或课程的一个阶段, 不够等级完成或部分等级完成。 }\end{array}$} \\
\hline
\end{tabular}

90. 并不是所有的类别和子类别的组合都存在或普遍存在。本文件中规定的三数字编码因此仅限于所用 的组合情况。附件II和II给出了这些编码的完整一览表。如果《国际教育标准分类法》的使用者鉴定 类别和子类别的另外组合，三数字编码表可使用留作补充标准的现行编码加以扩展。 
91. 联合国教科文组织统计研究所 (UIS) 是《国际教育标准分类法》的监管人, 因此负责发展、维 护、更新和修改这个参考分类方法。它还就有效和一致地使用《国际教育标准分类法》收集和分析 数据提供指导。联合国教科文组织统计研究所应该致力于维持与其它相关分类法监管者的联系, 以 便保证与其它相关标准框架的一致。

92. 统计研究所的其它责任包括:

- 说明如何使用分类方法的结构和细节来制作和列示统计资料;

- 推动将《国际教育标准分类法》用于国家间可比较统计；

- 对国家提供指导材料、培训和技术支持，以保证分类法在全世界的有效实施和应用;

- 建立监测机制, 追踪使用者就《国际教育标准分类法》使用时遇到的问题, 适当反馈（见第96 段）；和

- 与其它数据收集合作伙伴成立一个《国际教育标准分类法》委员会来审查此分类法, 对它的实施 提出建议（见第97段）。

93. 统计研究所计划编制一份操作手册, 以促进各国教育系统按《国际教育标准分类法》分类和图谱分 析（先针对正规教育课程和资格证书）。手册应就《国际教育标准分类法》的解释（包括某些国家 的例子）提供指导和注释。如果必要而且使用者提出要求, 额外的指导和培训材料会有提供。

94. 实施培训应通过地区研讨会, 技术援助和合作来安排, 以国家的需要和现有的能力为基础。统计研 究所将与数据收集合作伙伴就培训材料及其内容进行紧密合作。应特别注意的是将《国际教育标准 分类法》1997版的图谱分析转换至《国际教育标准分类法》2011版, 以及关于新的或改革过的课程 分类的指导。

95. 统计研究所计划就按照《国际教育标准分类法》编制的国家教育系统（正规教育课程和资格证书） 的图谱分析在其网站上维护一个数据库。该图谱分析将适时更新, 以便反映国家教育系统中随时间 的变化。

96. 为了保证遵从2011版《国际教育标准分类法》，实施中应建立质量保证机制。统计研究所计划与国 家和合作伙伴的数据收集机构（包括欧盟统计局和经合发组织）进行紧密合作，以保证图谱分析与 《国际教育标准分类法》一致和必要时更新。应与成员国和其它相关机构一起合作, 就正规国家教 育课程和资格证书的图谱分析，建立一个同行审查机制。 
97. 应组建一个《国际教育标准分类法》委员会, 向统计研究所就国家教育课程和资格证书的分类提供 咨询意见，审查《国际教育标准分类法》现行版本，鉴定可进一步发展的潜在领域，尽管修改《国 际教育标准分类法》不会在其范围。委员会应包括联合国教科文组织（联合国系统组织中的领头机 构）、其它相关，如果适当的话，分类法监管机构、和诸如经合发组织和欧盟统计局等主要教育 数据收集伙伴作为永久成员。委员会委员的构成应保持技术和地理上的平衡, 因此还应包括一些具 有《国际教育标准分类法》知识并代表世界不同地区的教育、统计和分类专家，作为非永久性的代 表，以及来自研究和用户社区的代表。 


\section{第九章《国际教育标准分类法》等级}

98. 以下各节对《国际教育标准分类法》的 9 个等级进行了界定。每节的结构如下:

A. 主要特点：描述不同《国际教育标准分类法》等级中课程的目标，授课的组织方法（教学过程的 特点和如果适用的话, 典型评估方法），以及课程的进入要求。对于某些《国际教育标准分类 法》等级, 课程的常用和熟知的国家名称标出来作为国家教育课程与《国际教育标准分类法》 等级之间的对应关系的可能例子。

B. 分类标准: 正式地界定如何采用主要标准和次要标准, 将教育课程分类为《国际教育标准分类法》 中的相应等级。关于《国际教育标准分类法》中“等级”的总体概念的进一步信息，见第5章。

C. 跨《国际教育标准分类法》等级的课程节：对超出一个《国际教育标准分类法》等级的教育课程 进行分类提供进一步指导。关于跨《国际教育标准分类法》等级教育课程的相关概念的进一步 信息，见第3章。

D. 补充标准：界定按照课程的定向、等级完成和通向更高《国际教育标准分类法》等级、课程持续 时间或在国家学位 / 资格证书中的定位来区分《国际教育标准分类法》等级内不同类型的课程的 特性。关于《国际教育标准分类法》的这些补充标准的进一步信息，见第5章。

E. 包括在《国际教育标准分类法》等级中的其它课程：表明不十分典型或非正规的教育课程（例如 特殊需要、二次机会或成人教育），不能符合所有分类标准（例如典型入学年龄），但在内容的 复杂程度上相当于已归类于这一《国际教育标准分类法》等级的课程。这些课程因此也归类于相 应的《国际教育标准分类法》等级。

F. 教育课程的分类：为分配给教育课程的ISCED-P等级、类别和子类别提供详细编码。

G. 受教育程度的分类：为分配给教育资格证书和对成功完成教育课程的类似测定的ISCED-A等 级、类别和子类别提供详细编码。还说明在哪些情况下需要将一个教育资格证书分类为不同的 ISCED-A等级, 而不是与通常从中获取资格证书的相应教育课程的ISCED-P等级。

99. 在说明《国际教育标准分类法》等级以后, 第10章提供把《国际教育标准分类法》2011版与 1997 版联系起来的对应关系表格（见表20和表21）。 


\section{《国际教育标准分类法》0级 早期儿童教育}

\section{A. 主要特点}

100. 《国际教育标准分类法》0级课程, 或早期儿童教育, 通常是使用整体方法设计, 用以支持儿童认 知、体格、社交和情感的早期发展, 引导年幼儿童进入有组织的家庭外授课。《国际教育标准分类 法》0级指包括一个有目的的教育内容的早期儿童课程。这些课程旨在开发融入学校和社会必需的 社会情感技能。它们还开发学术预备必需的某些技能以及为儿童进入初等教育做准备。

101. 在本等级, 课程不必是高度结构化的, 但目的是提供一套在安全环境中有组织和有目的的学习活 动。这些课程允许儿童在职员 / 教育者的指导下与其它儿童的互动, 通常通过启发性和以游戏为基 础的活动学习。

102. 《国际教育标准分类法》0级课程针对年龄未满进入《国际教育标准分类法》1级课程的儿童。《国 际教育标准分类法》0级课程有两个类别：早期儿童教育开发和学前教育。前者含有针对较年幼儿 童（在0-2岁范围）的教育内容, 而后者是针对年龄3岁至初等教育开始的儿童。

103. 《国际教育标准分类法》0级课程可有多种提法, 例如英语 “early childhood development (早前 儿童教育与开发）”、“play school（幼儿园）”、“reception（欢迎班）”、“pre-primary (学前)”“pre-school (学校前)”、或法语 “educación inicial (起步教育) ”。对于法语被称 为 “crèches (托儿所)”、英语被称为 “daycare centres（托儿中心）”、“nursery（托儿所）” 或法语被称为 “guarderías (幼儿园)” 的课程, 重要的是保证满足下述《国际教育标准分类法》 0级分类标准。出于国际可比性目的, 术语 “早期儿童教育 (early childhood education)”用于标 示《国际教育标准分类法》0级。

\section{B. 分类标准}

104. 关于早期儿童教育的定义，如下标准是相关的：

\section{主要标准}
a）课程的教育属性（见第105和106段）;
b）机构环境（见第107段）；
c）为其设置课程的儿童的典型目标年龄（见第102和108段）；和
d）课程强度和持续时间（见第110段）。

\section{次要标准}
a）职员资格证书（（见第111段）；
b）存在一个监管框架（见第112段）；和
c）通常不是义务教育的一部分（见第113段）。 
105. 早期儿童教育开发的教育属性以学习环境具备视觉兴奋和语言丰富为特点。这些课程培养自我表 达, 侧重掌握语言和使用语言进行有意义的交流。有活跃玩要的机会, 所以儿童能在看管下通过与 职员互动, 练习协调能力和运动技能。仅提供儿童护理（看管、营养和健康）的课程不包括在《国 际教育标准分类法》中。

106. 学前教育的教育属性以与同龄人及教育工作者的互动为特点, 儿童藉此提高语言使用和社交能力, 开始发展逻辑和推理技能, 以及随着思考进程进行交谈。给他们介绍字母和数学的概念, 鼓励他们 去探究周围的世界和环境。有看管的简单运动活动（如, 通过游戏和其它活动锻炼体能）和基于玩 要的活动可用作学习机会, 促进与同龄人的社交互动并发展技能、自理和学校准备。

107. 《国际教育标准分类法》0级课程常常是以学校为基础的, 或者是为一组儿童而组织的（例如以中 心为基础的、社区为基础的、家庭为基础的）。《国际教育标准分类法》0级不包括纯粹以家庭为 基础的安排，这些安排也许有一定目的但是没有组织成一个“课程”（例如儿童跟从父母、其它亲 属或朋友的非正式学习是不包括在《国际教育标准分类法》0级）。

108. 在《国际教育标准分类法》0级中, 早期儿童教育开发课程以年龄为0-2岁的幼儿为对象; 学前教育 课程以年龄3岁至《国际教育标准分类法》1级开始年龄的儿童为对象。学前教育年龄上限取决于进 入《国际教育标准分类法》1级（即初等教育）的理论年龄（见第117段）。

109. 综合早期儿童教育课程跨《国际教育标准分类法》0级两个子类别（即以年龄 0 岁至《国际教育标准 分类法》1级开始年龄儿童为对象的教育课程），在分类时需要特别考虑。对于按年数、阶段或周 期细分的课程：那些与第105段内容标准对应的课程应划分为早期儿童教育开发, 而那些与第106段 内容标准对应的课程应划分为学前教育。没有细分课程的地方, 应以参加者的年龄为基础分为两个 类别。

110. 《国际教育标准分类法》推荐如下最小强度和最少持续时间来增进跨国可比性：教育课程必须具备 至少相当于每天2小时和每年100天的教学活动，以归类于《国际教育标准分类法》。

111. 如果合适, 教育者的教学资格证书对区分在那些有如此要求的教育体制中的教育课程来说是一个 好的辅助标准。它有助于将早期儿童教育从无须要求明确经过教学培训过的职工的儿童护理中区 分出来。

112. 相应地, 存在一个相关的国家主管当局（例如教育部、其它相关部委或附属机构）所发布或公认的 参考或监管框架, 是对教育课程来说一个好的辅助标准。这包括描述给年幼儿童提供学习机会的指 导方针、标准或指示。

113. 在有义务学校教育的教育系统中, 设在义务教育开始前并满足上述标准的非义务教育课程划分为《国 际教育标准分类法》0级。此外，在某些国家，义务教育的第一个阶段或周期如果满足《国际教育标 准分类法》0级的标准，也可以划分到这个等级。因此，义务教育的开始不是一个将《国际教育标准 分类法》0级课程从《国际教育标准分类法》1级课程中区分开的充分标准, 尽管某些教育系统有这种 情况。 


\section{C. 跨《国际教育标准分类法》等级课程}

114. 跨《国际教育标准分类法》0和1级的教育课程, 在分类方面需要特别考虑。在初等教育包括部分早 期儿童教育的教育系统中, 只有符合第104段所给标准的那些年级、阶段或周期, 才应划为《国际 教育标准分类法》0级。符合第124段所给标准的年级、阶段或周期, 应划为《国际教育标准分类 法》1级。

115. 如果分类标准的应用没有在《国际教育标准分类法》0级和 1 级之间给出一个明确的界线, 建议 如下:

i) 对于按阶段组织的跨《国际教育标准分类法》0和1级课程而言, 最接近年龄6岁的阶段的结束应当 用作《国际教育标准分类法》0级和1级的转折点;

ii)对于不分阶段的跨《国际教育标准分类法》0和1级课程而言, 以6岁以下儿童为对象的年级应该划 分为《国际教育标准分类法》0级, 余下的年级应划分为《国际教育标准分类法》1级。

\section{D. 补充标准}

116. 区分《国际教育标准分类法》0级教育课程的一个标准 :

- 对象年龄组（见第102段）。

\section{E. 包括在《国际教育标准分类法》0级中的其它课程}

117. 《国际教育标准分类法》0级包括符合第104段所述标准、为有特殊需要的儿童开设的课程, 不考虑 这些儿童的年龄。

\section{F. 《国际教育标准分类法》0级教育课程的分类}

118. 在《国际教育标准分类法》0级教育课程中, 编码010为早期儿童教育开发课程, 编码020为学前教 育课程（见第102段）。不存在用第三个数字区分的子类别。 


\section{G. 《国际教育标准分类法》0级和1级的受教育程度分类}

119. 在对受教育程度分类方面，0级（低于初等教育）用于以下个人：

- 从未上过一个教育课程;

- 受过一些早期儿童教育（《国际教育标准分类法》0级）；或

- 受过一些初等教育但没有成功完成《国际教育标准分类法》1级（上或未上过《国际教育标准分 类法》0级）。

表4提供了与学前教育和初等教育有关的受教育程度分类编码。 


\section{《国际教育标准分类法》1级 初等教育}

\section{A. 主要特点}

120. 《国际教育标准分类法》1级课程, 或初等教育, 通常是为了给学生提供阅读、写作和数学的基本 技能（即识字和算术），以及为学习和理解知识及个人和社会发展的核心领域、准备初级中等教育 等奠定一个牢固的基础。它侧重于基础层面，几乎不涉及专业知识的学习。

121. 《国际教育标准分类法》1级（特别是在早期的年级）的教育活动, 通常采用一种综合方法, 围绕 单元、项目或广泛的学习范围进行组织, 而不就特定课目授课。有一个主要教师负责一组学生, 组 织学习过程, 但是一个班可能不止一个教师, 特别是在某些专门课目或单元方面。

122. 年龄通常是这个等级的唯一入学要求。入学的习惯或法定年龄常常是不低于5岁不大于7岁。这个 等级通常持续6年, 尽管其持续时间范围在4至7年之间。初等教育一般持续至年龄10至12岁（见第 132至134段）。一旦完成初等教育课程, 儿童可在《国际教育标准分类法》2级（初级中等教育） 继续教育。

123. 划为《国际教育标准分类法》1级的课程可有多种提法, 例如英语 “primary education（初等教 育）”、“elementary education or basic education（小学教育或基础教育）”（阶段一或较 低年级, 如果一个教育系统有跨《国际教育标准分类法》1和2级的课程））。出于国际可比性目 的, 术语 “初等教育 (primary education) ”用于标示《国际教育标准分类法》1级。

\section{B. 分类标准}

124. 在“初等教育” 定义方面, 如下标准是相关的:

\section{主要标准}

a）基础知识、技艺和能力方面的系统授课（见第125段）；

b) 典型的入学年龄和持续时间（见第122段）；和

c）一般由一个主要班级教师组织的授课（见第126段）。

\section{次要标准}

a）义务教育的一部分（见第127段）。

125. 《国际教育标准分类法》0级和1级之间的界线与一个教育系统内开始进行阅读、写作和数学方面的 系统讲授和学习的转变点相配合。尽管某些《国际教育标准分类法》0级课程也许已经提供阅读、 写作和数学方面的介绍, 但这些课程并没有在这些方面给予儿童牢固的基本技能, 因此不够达到划 入《国际教育标准分类法》1级的标准。进入国家特定的初等、小学或基础教育机构或课程, 一般 标志着从学前教育至初等教育的转变。 
126. 通常一个主要教师负责一群儿童, 采用综合方法, 围绕单元、项目或广泛的学习范围进行组织, 促 进学习进程（特别是在初等教育的早期）。然而, 一个班级可以有其它教师, 特别是在某些特定的 课目方面。《国际教育标准分类法》1级教师通常在核心课目的教学方法上受过训练。相比之下, 在《国际教育标准分类法》2级课程中有不止一个教师讲授不同课目, 他们常常在特定课目受过更 深入的训练。

127. 初等教育的开始通常与义务教育的开始相配合, 部分或全部学前教育已为义务的教育系统除外。因 此, 在义务教育立法的地方, 它开始于《国际教育标准分类法》1级或更早。

\section{C. 跨《国际教育标准分类法》等级课程}

128. 跨《国际教育标准分类法》0 和1级或 1 和 2 级的教育课程, 在分类方面需要特别考虑。对初等教育 属于8年以上教育课程一部分的教育体系, 只有符合第124段标准的年级、阶段或周期, 才应划为

《国际教育标准分类法》1级。符合第104段所给标准的任何年级、阶段或周期, 应划为《国际教 育标准分类法》0级, 而符合第143段所给标准的任何年级、阶段或周期, 应划为《国际教育标准 分类法》2级。

129. 如果使用这些分类标准没有在《国际教育标准分类法》0级和1级之间给出一个明确的界线, 确定《国 际教育标准分类法》0级结束和《国际教育标准分类法》1级开始的补充标准在第115段中提供。

130. 如果使用这些分类标准没有在《国际教育标准分类法》1级和2级之间给出一个明确的界线, 推荐 如下:

i) 对于按阶段组织的跨《国际教育标准分类法》1和2级课程而言, 最接近从《国际教育标准分类 法》1级开始后的6年的阶段的结束应用作《国际教育标准分类法》1级和2级的转变点;

ii) 对于不分阶段的跨《国际教育标准分类法》1和2级课程而言, 只有首先的6年应划为《国际教育 标准分类法》1级，余下的年数划为《国际教育标准分类法》2级（见第149段）。

\section{D. 补充标准}

131. 无

\section{E. 包括在《国际教育标准分类法》1级中的其它课程}

132. 《国际教育标准分类法》1级包括适合有特殊需要的个人的课程, 如果该课程在阅读、写作和数学 的基本技能方面提供系统的讲授和学习，而不考虑参加者的年龄。 
133. 本级还包括初等教育二次机会或再教育课程。这样的教育课程通常针对以下个人：

i) 在完成初等教育之前离校退学的个人, 使其再次进入教育系统并完成初等教育, 或

ii) 完成初等教育, 但希望进入一个仍未合格的教育课程或职业。参加者的年龄通常比《国际教育标 准分类法》1级对象年龄组的大（但不一定是成人）。

134. 为成人或年长于典型的《国际教育标准分类法》1级学生的青年开设的正规或非正规扫盲课程, 如 果内容的复杂程度与已划分初等教育的课程类似, 也包括在本级之中。

\section{F. 《国际教育标准分类法》1级教育课程的分类}

135. 所有《国际教育标准分类法》1级教育课程都编码为 100 。不存在用第二个或第三个数字区分的类别 或子类别。

\section{G. 《国际教育标准分类法》0级和1级的受教育程度分类}

136. 在为受教育程度编码时，对那些受过但未完成初等教育的个人的分类要特别考虑。

137. 关于受教育程度, 从《国际教育标准分类法》2级课程获得的公认资格证书, 如果不够《国际教育 标准分类法》2级完成或部分完成，则划分为《国际教育标准分类法》1级（例如，在《国际教育标 准分类法》2级持续时间少于2年或从《国际教育标准分类法》1级开始起的累计持续时间少于 8 年的 课程）。

138. 与《国际教育标准分类法》0级和1级课程, 以及从初级中等教育课程获得但不够被认可为完成或部 分完成《国际教育标准分类法》2级的资格证书有关的分类编码见表4。

\section{表4. 与《国际教育标准分类法》0至1级有关的受教育程度的分类编码（ISCED-A）}

\begin{tabular}{|l|l|c|l|c|l|}
\hline \multicolumn{2}{|c|}{ ISCED-A等级 } & \multicolumn{2}{c|}{} & \multicolumn{2}{c|}{ 子类别 } \\
\hline 0级 & 低于初等教育 & 01 & 从未上过教育课程 & 010 & 从未上过教育课程 \\
\cline { 3 - 6 } & 02 & 某些早期儿童教育 & 020 & 某些早期儿童教育 \\
\cline { 3 - 7 } & 03 & 某些初等教育（无等级完成） & 030 & 某些初等教育（无等级完成） \\
\hline 1级 & 初等教育 & 10 & 初等教育 & 100 & $\begin{array}{l}\text { 包括公认成功完成初级中等课程但不够 } \\
\text { 等级完成或部分等级完成 }\end{array}$ \\
\hline
\end{tabular}




\section{《国际教育标准分类法》2级 初级中等教育}

\section{A. 主要特点}

139. 《国际教育标准分类法》2级课程, 或初级中等教育, 一般是建立在《国际教育标准分类法》1级的 学习成果之上。通常, 其目标是为终身学习和人力开发奠定基础, 在这个基础上教育系统可以扩展 进一步的教育机会。某些教育系统也许已经在《国际教育标准分类法》2级提供职业教育课程, 以 便给人提供与就业相关的技能。

140. 本级课程通常围绕更加以课目为导向的课表进行组织, 就广泛的课目引入理论概念。教师通常经过 特定课目的教学训练, 并且比《国际教育标准分类法》1级更常见的是, 一个班的学生可有几位具 有所教课目的专门知识的教师。

141. 《国际教育标准分类法》2级开始于经过4-7年的《国际教育标准分类法》1级教育后, 6年《国际教 育标准分类法》1级为最常见的持续时间。进入《国际教育标准分类法》2级的学生年龄通常在10和 13岁之间（12岁是最常见的年龄）。

142. 划为《国际教育标准分类法》2级的课程可有多种提法，例如英语 “secondary school（中等 学校（阶段一/较低年级，如果存在一个跨《国际教育标准分类法》2和3级的课程））”、“junior secondary school（初级中等学校）”、“middle school（中学）”、或 “junior high school（初级 高中）”。如果一个课程跨《国际教育标准分类法》1和2级, 则常使用术语 “elementary education or basic school（初等教育或基础教育）”（阶段二/高年级））。出于国际可比性目的，术语 “初 级中等教育 (lower secondary education) ”用于标示《国际教育标准分类法》2级。

\section{B. 分类标准}

143. 在初级中等教育定义方面, 以下标准是相关的:

\section{主要标准}

a）转变至更多以课目为导向的授课（见第144段）；

b）入学要求（见第145段）；和

c）从《国际教育标准分类法》1级开始的累计持续时间（见第146段）。

\section{次要标准}
a）典型的入学年龄（见第141段）；
b）课目教师授课和教师资格证书（见第147段）；和
c）与义务教育的关系（见第148段）。

144. 《国际教育标准分类法》1级和2级之间的界线与教育系统中注重课目授课的转变点相配合。

145. 本级要求完成《国际教育标准分类法》1级, 或综合运用先前教育以及生活和工作经验学习《国际 教育标准分类法》2级内容的能力。特定国家进入某些或全部《国际教育标准分类法》2级课程可能 要求成功完成《国际教育标准分类法》1级或特定成绩水平。 
146. 《国际教育标准分类法》2级在《国际教育标准分类法》1级开始的8至11年教育后结束, 9年为最普 遍的累计持续时间。在《国际教育标准分类法》2级结束时, 学生年龄一般为14到16岁（最常见的 为15岁）。

147. 《国际教育标准分类法》2级要求的教师资格证书可能与《国际教育标准分类法》1级不同。《国际 教育标准分类法》2级教师通常在一个或多个特定课目以及教学上有资格。另外, 授课的组织会不 同于《国际教育标准分类法》1级, 因为一个班通常配有几个教师, 讲授各自学科或专业学科。

148. 在许多有义务教育立法的教育系统中, 初级中等教育的结束与义务（普通）教育的结束相配合。

\section{C. 跨《国际教育标准分类法》等级课程}

149. 跨《国际教育标准分类法》1和2级或2和3级的教育课程, 在分类方面需要特别考虑。只有符合第 143段标准的年级、阶段或周期, 才应划为《国际教育标准分类法》2级。符合第124段标准的年 级、阶段或周期, 应划为《国际教育标准分类法》1级, 而符合第166段标准的, 应划为《国际教育 标准分类法》3级。

150. 如果使用的分类标准没在《国际教育标准分类法》1级和2级之间给出一个明确的界线, 推荐使用 第130段中提供的标准确定《国际教育标准分类法》1级的结束和《国际教育标准分类法》2级的 开始。

151. 如果使用分类标准没在《国际教育标准分类法》2级和3级之间给出一个明确的界线, 推荐如下:

i) 对于按阶段组织的跨《国际教育标准分类法》2和3级课程而言, 最接近从《国际教育标准分类 法》1级开始后 9 年的阶段的结束应用作《国际教育标准分类法》2级和3级的转变点; 或

ii) 对于不分阶段的跨《国际教育标准分类法》2和3级课程而言, 只有处于《国际教育标准分类 法》1级结束至《国际教育标准分类法》1级开始后9年学校教育的结束之间的年级才应划为《国 际教育标准分类法》2级, 余下的年数划为《国际教育标准分类法》3级（见第171段）。

\section{D. 补充标准}

152. 两个标准对《国际教育标准分类法》2级教育课程作区分：

- 课程定向（见第153段）;

- 等级完成并通向更高《国际教育标准分类法》等级（见第154段）。

\section{课程定向}

153. 以下两个定向类别在第55段和第54段有定义:

- 普通; 和

- 职业。 


\section{等级完成并通向更高《国际教育标准分类法》等级}

154. 如下 4 个等级完成和通向子类别是为《国际教育标准分类法》2级定义的:

i) 未完成《国际教育标准分类法》2级（因此不通向更高《国际教育标准分类法》等级）: 短线终 端课程（或序列课程），在《国际教育标准分类法》2级持续时间少于两年, 或者从《国际教育 标准分类法》1级开始累计时间不足8年就结束。这些课程不给予通向《国际教育标准分类法》 3 级。成功完成这种课程不视为完成《国际教育标准分类法》2级。

ii) 部分完成《国际教育标准分类法》2级并不直接通向更高《国际教育标准分类法》等级: 课程 在《国际教育标准分类法》2级至少两年，从《国际教育标准分类法》1级开始的累计持续时间 至少 8 年, 是《国际教育标准分类法》2级序列课程中的部分, 但不是这个等级该序列的最后课 程。这些课程不给予直接通向《国际教育标准分类法》3级。成功完成这种课程仅视为部分完成 该等级（因为只有序列中的最终课程可能给予通向《国际教育标准分类法》3级）。

iii) 完成《国际教育标准分类法》2级但不直接通向更高等级: 课程在《国际教育标准分类法》2级 有至少两年的持续时间，从《国际教育标准分类法》1级开始至少8年的累计持续时间结束，但 是不给予通向《国际教育标准分类法》3级。虽然这些课程视为终端, 其成功完成符合完成《国 际教育标准分类法》2级。

iv) 完成《国际教育标准分类法》2级并直接通向更高《国际教育标准分类法》等级：给予直接通向 《国际教育标准分类法》3级的任何课程，不考虑在该等级的持续时间或从《国际教育标准分类 法》1级开始后的累计持续时间。

\section{E. 包括在《国际教育标准分类法》2级中的其它课程}

155. 《国际教育标准分类法》2级包括适合有特殊需要的个人的课程, 这些课程是建立在从《国际教育 标准分类法》1级开始的基本讲授和学习进程的基础上，和 / 或提供与就业相关的技能。

156. 本级还包括初级中等水平的二次机会或再教育课程。这类教育课程通常针对以下人：

i) 完成初等教育之后但在完成初级中等教育之前退出教育, 使其再次进入教育系统并完成初级中等 教育课程; 或

ii) 完成初级中等教育但希望进入一个其尚未合格的教育课程或职业。

参加者的年龄通常比《国际教育标准分类法》2级对象年龄组的大。

157. 本级还包括就内容复杂程度而言与已归入本级其它课程所提供的等同教育的成人教育课程。 


\section{F. 《国际教育标准分类法》2级教育课程的分类}

158. 使用两个补充标准允许报告定向类别与等级完成和通向更高《国际教育标准分类法》等级子类别。 初级中等教育课程的编码如表5所示。

\section{表5.《国际教育标准分类法》2级教育课程分类编码（ISCED-P）}

\begin{tabular}{|c|c|c|c|}
\hline \multicolumn{2}{|c|}{$\begin{array}{l}\text { 类别 } \\
\text { (定向) }\end{array}$} & \multicolumn{2}{|r|}{ （等级完成和通向更高《国际教育标准分类法》等级） } \\
\hline \multirow[t]{4}{*}{24} & \multirow{4}{*}{$\begin{array}{l}\text { 初级中等 } \\
\text { 普通教育 }\end{array}$} & 241 & 不够等级完成或部分等级完成, 不直接通向高级中等教育 \\
\hline & & 242 & 足够部分等级完成，不直接通向高级中等教育 \\
\hline & & 243 & 足够等级完成, 不直接通向高级中等教育 \\
\hline & & 244 & 足够等级完成, 直接通向高级中等教育 \\
\hline \multirow[t]{4}{*}{25} & \multirow{4}{*}{$\begin{array}{l}\text { 初级中等 } \\
\text { 职业教育 }\end{array}$} & 251 & 不够等级完成或部分等级完成, 不直接通向高级中等教育 \\
\hline & & 252 & 足够部分等级完成, 不直接通向高级中等教育 \\
\hline & & 253 & 足够等级完成, 不直接通向高级中等教育 \\
\hline & & 254 & 足够等级完成, 直接通向高级中等教育 \\
\hline
\end{tabular}

\section{G. 《国际教育标准分类法》2级的受教育程度分类}

159. 在受教育程度方面, 从《国际教育标准分类法》2级课程获得的公认资格证书不视为足够完成或部 分完成《国际教育标准分类法》2级课程, 则划入《国际教育标准分类法》1级（见表4）。

160. 同样, 从《国际教育标准分类法》3级课程获得的公认资格证书不够视为完成或部分完成《国际教 育标准分类法》3级，则划入《国际教育标准分类法》2级。

161. 与初级中等教育有关的受教育程度和从高级中等课程获得不够等级完成或部分等级完成的资格证书 的分类编码如表6所示。 
表6. 与《国际教育标准分类法》2级有关的受教育程度的分类编码（ISCED-A）

\begin{tabular}{|c|c|c|c|}
\hline \multicolumn{2}{|r|}{$\begin{array}{l}\text { 类别 } \\
\text { (定向） }\end{array}$} & \multicolumn{2}{|r|}{ (等级完成和通向更高《国际教育标准分类法》等级) } \\
\hline 10 & 初等教育 & 100 & 公认成功完成一个初级中等课程但不够等级完成或部分等级完成 \\
\hline \multirow[t]{3}{*}{24} & \multirow[t]{3}{*}{ 初级中等普通教育 } & 242 & 部分等级完成, 不直接通向高级中等教育 \\
\hline & & 243 & 等级完成，不直接通向高级中等教育 \\
\hline & & 244 & 等级完成，直接通向高级中等教育1 \\
\hline \multirow[t]{3}{*}{25} & \multirow[t]{3}{*}{ 初级中等职业教育 } & 252 & 部分等级完成, 不直接通向高级中等教育 \\
\hline & & 253 & 等级完成, 不直接通向高级中等教育 \\
\hline & & 254 & 等级完成，直接通向高级中等教育 1 \\
\hline
\end{tabular}




\section{《国际教育标准分类法》3级 高级中等教育}

\section{A. 主要特点}

162. 《国际教育标准分类法》3级课程, 或高级中等教育, 通常旨在完成中等教育, 为高等教育做准 备, 或者提供与就业有关的技能, 或者两者都是。

163. 本级课程给学生提供比《国际教育标准分类法》2级课程更多样、更专业和程度更深的授课。这些 课程有更多的差异, 选修和能力组别的范围增加。教师在所授的课目或专业学科上通常有很高的资 历, 特别是在高年级。

164. 《国际教育标准分类法》3级从《国际教育标准分类法》1级开始后8到11年教育后开始。学生通常 在14和16岁之间进入本级。《国际教育标准分类法》3级通常在从《国际教育标准分类法》1级教育 开始后12或13年（或年龄大约17岁或18岁）结束, 12年为最常见的累计持续时间。但是, 在跨教 育系统中, 高级中等教育结业可能在《国际教育标准分类法》1级开始以来从通常的11年到13年教 育的范围。

165. 划为《国际教育标准分类法》3级的课程可有多种提法, 例如英语 “secondary school (stage two / upper grades）（中等学校（阶段二/高年级））”、“senior secondary school or（senior） high school (高级中等学校或 (高级) 中学)”。出于国际可比性目的, 术语 “高级中等教育 (upper secondary education）”用于标示《国际教育标准分类法》3级。

\section{B. 分类标准}

166. 在高级中等教育定义方面, 如下标准是相关的:

\section{主要标准}

a）普通和职业中等教育的第二/最后阶段（见第167段）；

b) 入学要求（见第168段）; 和

c）《国际教育标准分类法》1级开始以来的累计持续时间（见第164段）。

\section{次要标准}
a) 更多差异的课程, 选修和能力组别范围增加（见第169段）；和
b）教师资格证书（见第170段）。

167. 构成中等教育第二/最后阶段的课程可能或是普通或是职业的《国际教育标准分类法》3级课程。 其中某些课程准予直接通向《国际教育标准分类法》4级、和 / 或5、6或7级。当鉴定《国际教育标 准分类法》等级之间的转变点时, 普通和职业路径之间的对应关系应当保证。 
168. 《国际教育标准分类法》3级要求完成初级中等教育（《国际教育标准分类法》2级）, 或综合考虑 先前教育及生活和工作经验处理《国际教育标准分类法》3级内容的能力。进入某些或所有《国际 教育标准分类法》3级课程可能要求拥有特别的《国际教育标准分类法》2级资格证书或特定的成绩 水平。

169. 《国际教育标准分类法》2级到3级的转变, 与一个教育系统的转变点相配合, 其课程给学生在特定 课目或学科提供更多样、更专业和程度更深的的授课。课程一般地更加有差异, 有更大的选修和能 力组别范围。

170. 教师资格证书的标准在《国际教育标准分类法》3级可能与《国际教育标准分类法》2级不同。除了 教学培训以外, 教师在所教的课目方面可能更加合格。

\section{C. 跨《国际教育标准分类法》等级课程}

171. 跨《国际教育标准分类法》2和3级或3和5级的教育课程, 在分类方面需要特别考虑。只有符合第 166段所给标准的年级、阶段或周期, 才应划为《国际教育标准分类法》3级。符合第143段所给标 准的年级、阶段或周期, 应划为《国际教育标准分类法》2级, 而符合第211段所给标准的, 应划为 《国际教育标准分类法》5级。

172. 如果使用分类标准没有在《国际教育标准分类法》2级和3级之间给出一个明确的界线, 确定《国际 教育标准分类法》2级结束和《国际教育标准分类法》3级开始的标准在第151段提供。

173. 如果一个 《国际教育标准分类法》3级职业课程的理论持续时间, 比同一教育系统的一个 《国际教 育标准分类法》3级普通课程的理论持续时间，长2年或更长，那么这个课程应视为跨高级中等教育 (《国际教育标准分类法》3级) 和中等后非高等教育 (《国际教育标准分类法》4级) 或短线高等 教育（《国际教育标准分类法》5级）。那些超过《国际教育标准分类法》3级普通课程的年级、阶 段或周期，应根据其内容的复杂程度划为《国际教育标准分类法》4或5级。

\section{D. 补充标准}

174. 两个标准对《国际教育标准分类法》3级教育课程进行区分:

- 课程定向（第175段）；和

- 等级完成并通向更高《国际教育标准分类法》等级（第176段）。

\section{课程定向}

175. 以下两个定向类别在第55段和第54段定义:

- 普通; 和

- 职业。 


\section{等级完成并通向更高《国际教育标准分类法》等级}

176. 如下四个等级完成和通向子类别是为《国际教育标准分类法》3级定义的:

i) 未完成《国际教育标准分类法》3级（因此不直接通向在《国际教育标准分类法》5、6或7级的第 一个高等课程）：短线终端课程（或序列课程），在《国际教育标准分类法》3级有少于2年的持 续时间，或在从《国际教育标准分类法》1级开始后少于11年的累计持续时间结束。这些课程不 直接通向《国际教育标准分类法》5、6或7级。成功完成这样的课程不视为完成《国际教育标准 分类法》3级。也注意这些课程也不直接通向《国际教育标准分类法》4级。

ii) 部分完成《国际教育标准分类法》3级但不直接通向在《国际教育标准分类法》5、6或7级的第一 个高等课程: 课程在《国际教育标准分类法》3级至少 2 年, 从《国际教育标准分类法》1级开始 后至少11年的累计持续时间, 是《国际教育标准分类法》3级序列课程的一部分, 但不是本级该 序列的最后课程。这些课程不直接通向《国际教育标准分类法》5、6或7级。成功完成这样的课 程视为是仅部分完成 (只有序列课程的最后课程可能通向《国际教育标准分类法》5、6或7级的 高等教育）。也注意这些课程也不直接通向《国际教育标准分类法》4级。

iii) 完成《国际教育标准分类法》3级但不直接通向在《国际教育标准分类法》5、6或7级的第一个高 等课程: 课程在《国际教育标准分类法》3级有至少2年持续时间或从《国际教育标准分类法》1 级开始至少11年的累计持续时间后才结束。这些课程可能是终端的或直接通向《国际教育标准分 类法》4级。成功完成这样的课程符合完成《国际教育标准分类法》3级。

iv) 完成《国际教育标准分类法》3级并直接通向在《国际教育标准分类法》5、6或7级的第一个高等 课程：给予直接通向在《国际教育标准分类法》5、6或7级的第一个高等课程的任何课程，不考 虑其在3级的持续时间或从《国际教育标准分类法》1级开始的累计持续时间。这些课程也可直接 通向《国际教育标准分类法》4级。

\section{E. 包括在《国际教育标准分类法》3级中的其它课程}

177. 《国际教育标准分类法》3级包括适合有特殊需要的个人的课程, 在内容的复杂程度上相当于已归 于《国际教育标准分类法》3级的课程。

178. 本级可以包括某些二期职业课程, 该二期期末的转变点与该系统提供的其它（主要是普通）路径的 等级之间的转变点相对应。

179. 本级还包括高级中等二次机会或再教育课程。这样的教育课程通常针对以下个人：

i) 完成高级中等教育之前退出, 使其再次进入教育系统并完成高级中等教育; 或

ii) 完成高级中等教育, 希望进入未曾取得资格的课程或职业。

参加者通常比《国际教育标准分类法》3级对象年龄组的大。

180. 本级还包括在内容的复杂程度上等同于已归入本级课程的成人教育课程。 


\section{F. 《国际教育标准分类法》3级教育课程的分类}

181. 使用两个补充标准允许报告定向类别与等级完成和通向更高《国际教育标准分类法》等级子类 别。并非所有定向与完成和通向的组合在教育系统中都存在或者普遍存在。高级中等教育课程编 码如表7所示。

\section{表7.《国际教育标准分类法》3级教育课程的分类编码（ISCED-P）}

\begin{tabular}{|c|c|c|c|}
\hline \multicolumn{2}{|r|}{$\begin{array}{l}\text { 类别 } \\
\text { (定向） }\end{array}$} & \multicolumn{2}{|r|}{ (等级完成和通向更高《国际教育标准分类法》等级课程) } \\
\hline \multirow[t]{4}{*}{34} & \multirow[t]{4}{*}{ 高级中等普通教育 } & 341 & 不够等级完成或部分等级完成, 不直接通向中等后非高等教育或高等教育 \\
\hline & & 342 & 足够部分等级完成，不直接通向中等后非高等教育或高等教育 \\
\hline & & 343 & 足够等级完成, 不直接通向高等教育（但可直接通向中等后非高等教育） \\
\hline & & 344 & 足够等级完成，直接通向高等教育（也可给予直接通向中等后非高等教育） \\
\hline \multirow[t]{4}{*}{35} & \multirow[t]{4}{*}{ 高级中等职业教育 } & 351 & 不够等级完成或部分等级完成, 不直接通向中等后非高等教育或高等教育 \\
\hline & & 352 & 足够部分等级完成, 不直接通向中等后非高等教育或高等教育 \\
\hline & & 353 & 足够等级完成, 不直接通向高等教育 (但可给予直接通向中等后非高等教育) \\
\hline & & 354 & 足够等级完成，直接通向高等教育（也可给予直接通向中等后非高等教育） \\
\hline
\end{tabular}

\section{G. 《国际教育标准分类法》3级的受教育程度的分类}

182. 在受教育程度方面, 《国际教育标准分类法》3级课程的公认资格证书, 如果视为不够《国际教育 标准分类法》3级完成, 则划入《国际教育标准分类法》2级。

183. 同样地, 《国际教育标准分类法》4级课程的公认资格证书, 如果视为不够《国际教育标准分类 法》4级完成, 则划入《国际教育标准分类法》3级。

184. 与高级中等教育课程和资格证书有关的受教育程度分类编码如表8所示。 
表8. 与《国际教育标准分类法》3级有关的受教育程度分类编码 (ISCED-A)

\begin{tabular}{|c|c|c|c|}
\hline \multicolumn{2}{|r|}{$\begin{array}{l}\text { 类别 } \\
\text { （定向） }\end{array}$} & \multicolumn{2}{|r|}{$\begin{array}{c}\text { 子类别 } \\
\text { （等级完成和通向更高《国际教育标准分类法》等级） }\end{array}$} \\
\hline 24 & 初级中等普通教育 & 244 & 公认成功完成一个高级中等教育普通课程, 不够等级或部分等级完成 \\
\hline 25 & 初级中等职业教育 & 254 & 公认成功完成一个高级中等职业教育课程, 不够等级或部分等级完成 \\
\hline \multirow[t]{3}{*}{34} & \multirow[t]{3}{*}{ 高级中等普通教育 } & 342 & 部分等级完成, 不直接通向中等后非高等教育或高等教育 \\
\hline & & 343 & 等级完成, 不直接通向高等教育（但可给予直接通向中等后非高等教育） \\
\hline & & 344 & 等级完成, 直接通向高等教育1（也可给予直接通向中等后非高等教育） \\
\hline \multirow[t]{3}{*}{35} & \multirow[t]{3}{*}{ 高级中等职业教育 } & 352 & 部分等级完成, 不直接通向中等后非高等教育或高等教育 \\
\hline & & 353 & 等级完成, 不直接通向高等教育 (但可给予直接通向中等后非高等教育) \\
\hline & & 354 & 等级完成, 直接通向高等教育 1 (也可给予直接通向中等后非高等教育) \\
\hline
\end{tabular}




\section{《国际教育标准分类法》4级 中等后非高等教育}

\section{A. 主要特点}

185. 中等后非高等教育是在中等教育的基础之上提供学习经历，为进入劳务市场和高等教育做准备。 它针对那些期望获得的知识、技艺和能力低于高等教育复杂程度的个人。设置《国际教育标准分 类法》4级课程, 或中等后非高等教育, 一般是给那些完成《国际教育标准分类法》3级提供他们 的《国际教育标准分类法》3级继续至高等教育或就业所需有的非高等资格证书。例如，《国际教 育标准分类法》3级普通课程毕业生可选择去完成一个非高等的职业资格证书; 或者《国际教育标 准分类法》3级职业课程毕业生可选择提高他们资格证书的级别或更加专业。《国际教育标准分类 法》4级课程的内容不够复杂, 不能视为是高等教育课程, 尽管其明显地属于中等后。

186. 进入《国际教育标准分类法》4级课程, 要求完成《国际教育标准分类法》3级课程。但是, 这些入 学要求可能低于在《国际教育标准分类法》5、6或7级的高等教育课程。

187. 通常, 这级课程是给直接进入劳务市场设置的。在某些教育系统中, 本级有普通课程。这样的课程 通常针对那些已完成《国际教育标准分类法》3级但想增加进入高等教育机会的学生们。

188. 划入《国际教育标准分类法》4级的课程可有多种提法，例如英语 “technician diploma（技师文 凭)”、“primary professional education（初级专业教育）”、法语 “préparation aux carrières administratives（行政职业准备）”。出于国际可比性目的，术语“中等后非高等教育（postsecondary non-tertiary education）”用于标示《国际教育标准分类法》4级。

\section{B. 分类标准}

189. 关于中等后非高等教育的定义, 如下标准是相关的:

\section{主要标准}

a）定向（见第190段）；

b) 内容的复杂程度, 高于《国际教育标准分类法》3级，低于高等教育等级（见第191段）；和

c）入学要求（见第186段）。

\section{次要标准}

无。

190. 《国际教育标准分类法》4级课程不视为是高等教育, 通常是为劳务市场而准备的职业性最终课 程。某些教育系统可能有本级的普通课程。旨在复习《国际教育标准分类法》3级内容的课程, 比 如旨在帮助学生准备高等教育入学考试，应包括在《国际教育标准分类法》3级。 
191. 《国际教育标准分类法》4级课程, 通常是为了拓展而不是深化已完成《国际教育标准分类法》3级 课程参加者的知识、技艺和能力。课程通常不比《国际教育标准分类法》3级课程明显高级, 但是 其内容通常却比高级中等教育更加专业或详细。课程明显不如高等教育等级高级, 可由各种各样的 机构部门提供, 而不仅由那些认定为中等后非高等教育机构提供。

\section{C. 跨《国际教育标准分类法》等级课程}

192. 不适用。

\section{D. 补充标准}

193. 两个标准对《国际教育标准分类法》4级教育课程加以区分：

- 课程定向（见第194段）；和

- 等级完成并通向更高等级《国际教育标准分类法》课程（见第195段）。

\section{课程定向}

194. 以下两个定向类别在第55段和第54段定义:

- 普通; 和

- 职业。

\section{等级完成和通向更高《国际教育标准分类法》等级}

195. 如下三个等级完成和通向子类别是为《国际教育标准分类法》4级定义的:

-未完成《国际教育标准分类法》4级: 单元或阶段课程太短不够等级完成。这些课程不通向在《国际 教育标准分类法》5,6或7级的第一个高等课程。成功完成这样的单元或阶段课程不视为完成《国际 教育标准分类法》4级。

- 完成《国际教育标准分类法》4级但不直接通向在《国际教育标准分类法》5、6或7级的第一个高 等课程：课程主要为直接进入劳务市场而设置的; 和

- 完成《国际教育标准分类法》4级并直接通向在《国际教育标准分类法》5、6或7级的第一个高等 课程：课程主要为扩展通向高等教育而设置的。

\section{E. 包括在《国际教育标准分类法》4级中的其它课程}

196. 本级还包括在教育内容的复杂程度上类似于已划入本级课程的教育的成人教育课程。

\section{F. 《国际教育标准分类法》4级教育课程的分类}

197. 使用两个补充标准用允许报告定向类别与完成和通向子类别。并非所有类别和子类别的组合在各教 育系统中存在或者普遍存在。中等后非高等教育的编码如表9所示。 


\section{表9.《国际教育标准分类法》4级教育课程分类编码（ISCED-P）}

\begin{tabular}{|c|c|c|c|}
\hline \multicolumn{2}{|r|}{$\begin{array}{l}\text { 类别 } \\
\text { （定向） }\end{array}$} & \multicolumn{2}{|r|}{ (等级完成并通向更高 《国际教育标准分类法》等级) } \\
\hline \multirow[t]{3}{*}{44} & \multirow{3}{*}{$\begin{array}{l}\text { 中等后非高等普通 } \\
\text { 教育 }\end{array}$} & 441 & 不够等级完成, 不直接通向高等教育 \\
\hline & & 443 & 足够等级完成, 不直接通向高等教育 \\
\hline & & 444 & 足够等级完成, 直接通向高等教育 \\
\hline \multirow[t]{3}{*}{45} & \multirow{3}{*}{$\begin{array}{l}\text { 中等后非高等职业 } \\
\text { 教育 }\end{array}$} & 451 & 不够等级完成, 不直接通向高等教育 \\
\hline & & 453 & 足够等级完成, 不直接通向高等教育 \\
\hline & & 454 & 足够等级完成, 直接通向高等教育 \\
\hline
\end{tabular}

\section{G. 《国际教育标准分类法》4级受教育程度分类}

198. 在受教育程度方面, 从成功完成《国际教育标准分类法》5级课程的一个阶段获得的公认中间资格 证书，如视为不够完成《国际教育标准分类法》5级, 则划分为《国际教育标准分类法》4级。

199. 与中等后非高等资格证书有关的受教育程度分类编码如表10所示。

\section{表10.《国际教育标准分类法》4级受教育程度分类编码（ISCED-A）}

\begin{tabular}{|c|c|c|c|}
\hline \multicolumn{2}{|r|}{$\begin{array}{l}\text { 兴别 } \\
\text { （定向） }\end{array}$} & \multicolumn{2}{|r|}{ (等级完成并通向更高《国际教育标准分类法》等级) } \\
\hline 34 & 高级中等普通教育 & 344 & 公认成功完成一个中等后非高等普通课程的阶段但不够等级完成 \\
\hline 35 & 高级中等职业教育 & 354 & 公认成功完成一个中等后非高等职业课程的阶段但不够等级完成 \\
\hline \multirow[t]{2}{*}{44} & \multirow{2}{*}{$\begin{array}{l}\text { 中等后非高等普通 } \\
\text { 教育 }\end{array}$} & 443 & 等级完成, 不直接通向高等教育 \\
\hline & & 444 & 等级完成, 直接通向高等教育 1 \\
\hline \multirow[t]{2}{*}{45} & \multirow{2}{*}{$\begin{array}{l}\text { 中等后非高等职业 } \\
\text { 教育 }\end{array}$} & 453 & 等级完成, 不直接通向高等教育 \\
\hline & & 454 & 等级完成, 直接通向高等教育 1 \\
\hline
\end{tabular}




\section{高等教育}

200. 高等教育是建立在中等教育之上, 在专业化的教育学科提供学习活动。它以高度复杂和专业化的学 习为目标。高等教育包括通常所理解的学术教育, 还包括高级职业或专业教育。它包括《国际教育 标准分类法》5、6、7、8级, 分别标示为短线高等教育、学士或等同水平、硕士或等同水平, 和博 士或等同水平。与较低《国际教育标准分类法》等级相比, 高等教育课程的内容更加复杂和高级。

201. 《国际教育标准分类法》5、6或7级的第一个课程要求成功完成《国际教育标准分类法》3级并给予 直接通向第一个高等教育课程的课程。从《国际教育标准分类法》4级通向第一个高等教育课程也 是可能的。除资格证书要求以外, 进入这些等级的教育课程可能取决于课目选择和 / 或在《国际教 育标准分类法》3或4级达到的成绩。而且, 还可能要求参加并通过入学考试。

202. 在高等教育中, 一个教育课程总是划分在与根据成功完成而授予资格证书的等级相同的等级（除非 一个课程被部分地划分在《国际教育标准分类法》3级，见第173段）。因此，与《国际教育标准分 类法》0、1、2和3级相比, 跨《国际教育标准分类法》等级的课程概念不适用于高等教育。

203. 高等教育课程授予的资格证书之间通常存在一个清晰的层次结构。但是, 不像《国际教育标准分类 法》1、2、3和4级的课程, 《国际教育标准分类法》5、6和7级的国家课程可平行存在, 而不是一 个等级连续地建立在另一个等级上。完成一个《国际教育标准分类法》3或4级课程, 可给予通向一 系列在《国际教育标准分类法》5、6或7级的第一个高等教育课程, 这取决于在一个特定教育系统 的应用程度, 和 / 或可能指定的另外入学要求。这些包括:

- 在《国际教育标准分类法》5级的短线高等教育课程（至少2年）；

- 在《国际教育标准分类法》6级的学士或等同的第一学位课程（3-4年）;

- 在《国际教育标准分类法》6级的学士或等同的长线第一学位课程（长于4年）; 或

- 在《国际教育标准分类法》7级的硕士或等同的长线第一学位课程（至少5年）。

204. 高等级别课程之间的转变不是常常有清楚的区分, 有可能合并课程, 将一个课程的学分转入另一个 课程。在某些情况, 从以前完成的教育课程得到的学分也可算来完成一个更高《国际教育标准分类 法》等级的课程。例如, 在《国际教育标准分类法》5级课程所得的学分可减少完成一个6级课程所 要求的学分数或学习持续时间。在某些系统, 个人可在完成《国际教育标准分类法》5级课程后, 转入一个《国际教育标准分类法》6级课程, 前者可减少完成《国际教育标准分类法》6级课程所要 求的时间。其它的可直接从《国际教育标准分类法》3级进入到《国际教育标准分类法》6或7级。 在许多教育系统中, 大多数学生必须首先完成《国际教育标准分类法》6级才获准进入《国际教育 标准分类法》7级。

205. 进入《国际教育标准分类法》8级, 通常要求成功完成《国际教育标准分类法》7级。 
206. 图1 显示高等教育课程类别和它们之间的路径。

图1.《国际教育标准分类法》高等教育路径

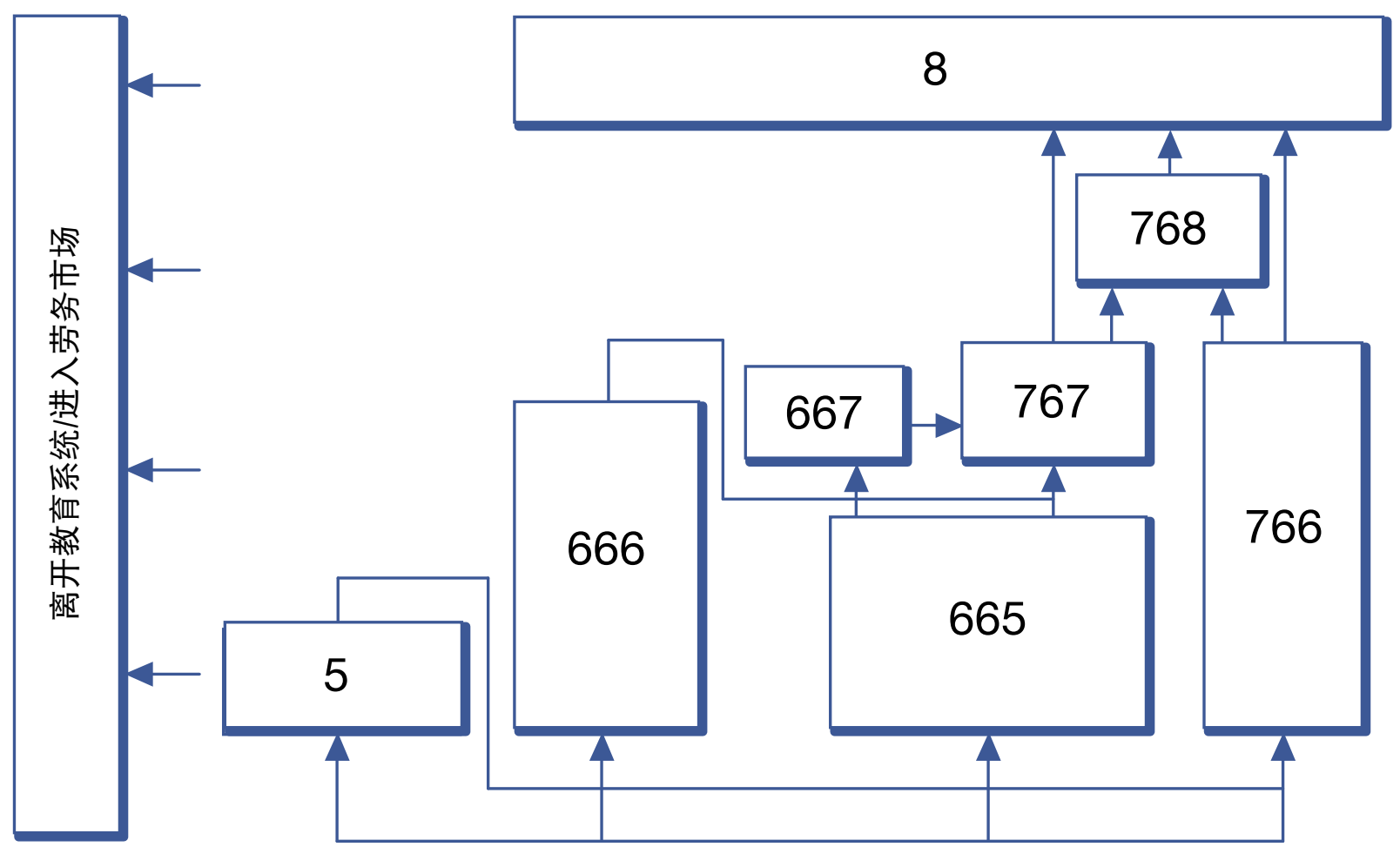

完成《国际教育标准分类法》3或4级,直接通向《国际教育 标准分类法》5、6或7级的第一个高等教育课程 


\section{《国际教育标准分类法》5级 短线高等教育}

\section{A. 主要特点}

207. 设置《国际教育标准分类法》5级课程, 或短线高等教育, 通常是为了给参加者提供专业知识、技 艺和能力。通常, 这些课程是基于实用和特定职业, 培训学生进入劳务市场。但是, 这些课程也能 提供一条通向其它高等教育课程的途径。学术性高等教育课程, 若低于学士或等同课程, 也划分在 《国际教育标准分类法》5级。

208. 进入《国际教育标准分类法》5级课程, 要求成功完成《国际教育标准分类法》3或4级且通向高等 教育。《国际教育标准分类法》5级课程, 与《国际教育标准分类法》3 和4级课程相比, 有更复杂 的内容, 但是与《国际教育标准分类法》6级课程相比, 时间短并且通常更少注重理论。

209. 尽管设置《国际教育标准分类法》5级课程的目的通常是为就业而准备的, 但是它们可给与学分, 用于转入《国际教育标准分类法》6或7级课程。在某些教育系统中, 一些人完成这些《国际教育标 准分类法》5级课程后, 可继续参加《国际教育标准分类法》6级 (学士或等同水平) 教育或长线第 一学位《国际教育标准分类法》7级（硕士或等同水平）课程。

210. 划入《国际教育标准分类法》5级的课程可有多种提法, 例如英语 “ (higher) technicaleducation ( (高级) 技术教育) ”、“community college education（社区大学教育）”、“technician or advanced / higher vocational training（技师或高级职业培训）”、“associate degree（副学位）” 或法语 “bac+2（两年制学士）”。出于国际可比性目的, 术语 “短线高等教育（short-cycle tertiary education）”用于标示《国际教育标准分类法》5级。

\section{B. 分类标准}

211. 在短线高等教育的定义方面, 如下标准是相关的:

\section{主要标准}

a）短线高等教育课程的内容（见第212段）；

b) 入学要求（见第208段）；和

c）等级的最短持续时间（见第213段）。

\section{次要标准}
a）机构转变点（见第214段）；和
b）等级的典型持续时间（见第213段）。

212. 《国际教育标准分类法》5级处于高等教育的最低级。本级课程的内容比中等（《国际教育标准分 类法》3级) 或中等后非高等教育（《国际教育标准分类法》4级）复杂, 但不如《国际教育标准分 类法》6级（学士或等同水平）课程。

213. 《国际教育标准分类法》5级有最短为 2 年的持续时间, 一般但不总是短于3年。在那些资格证书通 过学分积累而授予的有单元课程的教育系统中, 要求有可比的时间量与强度。 
214. 非高等至高等教育机构的转变点能帮助鉴定高级中等教育（《国际教育标准分类法》3级）、中等 后非高等教育（《国际教育标准分类法》4级）和高等教育的界线。《国际教育标准分类法》5级课 程通常由与《国际教育标准分类法》6、7、8级课程不同的教育机构提供。

\section{C. 跨《国际教育标准分类法》等级课程}

215. 跨《国际教育标准分类法》3和5级的教育课程在分类方面需要特别考虑。只有那些符合第211段所 给标准的年级、阶段或周期才应划为《国际教育标准分类法》5级。那些符合第166段所给标准的年 级、阶段或周期应划为 《国际教育标准分类法》3级。如果使用分类标准没有在《国际教育标准分 类法》3级和5级之间给出一个明确的界线, 确定《国际教育标准分类法》3级结束和《国际教育标 准分类法》5级开始的标准在第173段提供。

\section{D. 补充标准}

216. 两个标准对《国际教育标准分类法》5级教育课程加以区分：

- 课程定向（见第217段）；和

・ 等级完成（见第218段）。

\section{课程定向}

217. 以下两个定向类别在第55段和54段定义:

- 普通; 和

- 职业。

学术和专业课程的定义研究出来后, 将用于《国际教育标准分类法》5级的定向类别, 取代普通和 职业类别。

\section{等级完成}

218. 两个等级完成类别是为《国际教育标准分类法》5级定义的:

-未完成《国际教育标准分类法》5级：阶段（或课程）在《国际教育标准分类法》5级有少于2年的 持续时间，因此不够完成《国际教育标准分类法》5级。

- 完成《国际教育标准分类法》5级：课程在《国际教育标准分类法》5级有2年或更长的持续时间， 因此足够完成《国际教育标准分类法》5级。

\section{E. 包括在《国际教育标准分类法》5级中的其它课程}

219. 本级包括在内容的复杂程度上等同于已归入本级的课程所给的成人教育或继续教育课程。

\section{F. 《国际教育标准分类法》5级教育课程的分类}

220. 使用两个补充标准允许报告定向类别与等级完成子类别。用于《国际教育标准分类法》5级的编码 在表11中提供。 
表11.《国际教育标准分类法》5级教育课程分类编码（ISCED-P）

\begin{tabular}{|c|c|c|c|}
\hline \multicolumn{2}{|r|}{$\begin{array}{l}\text { 类别 } \\
\text { （定向） }\end{array}$} & \multicolumn{2}{|r|}{$\begin{array}{c}\text { 子类别 } \\
\text { (等级完成) }\end{array}$} \\
\hline \multirow[t]{2}{*}{54} & \multirow[t]{2}{*}{ 短线高等普通教育1 } & 541 & 不够等级完成 \\
\hline & & 544 & 足够等级完成 \\
\hline \multirow[t]{2}{*}{55} & \multirow[t]{2}{*}{ 短线高等职业教育1 } & 551 & 不够等级完成 \\
\hline & & 554 & 足够等级完成 \\
\hline
\end{tabular}

\section{G. 《国际教育标准分类法》5级受教育程度分类}

221. 在受教育程度方面, 从成功完成《国际教育标准分类法》5级的阶段（或课程）获得公认的中间资 格证书, 如果不够《国际教育标准分类法》5级完成, 则划分为《国际教育标准分类法》4级。参加 却没有获得公认成功完成《国际教育标准分类法》5级的一个课程, 不用于确定受教育程度等级。

222. 从成功完成课程一个阶段（在第一学位前）获得公认的中间资格证书不视为《国际教育标准分类 法》6级完成，划分为受教育程度方面的《国际教育标准分类法》5级。

223. 与《国际教育标准分类法》5级有关的受教育程度分类编码如表12所示。

\section{表12. 与《国际教育标准分类法》5级有关的受教育程度分类编码（ISCED-A）}

\begin{tabular}{|c|c|c|c|}
\hline \multicolumn{2}{|r|}{$\begin{array}{l}\text { 类别 } \\
\text { (定向) }\end{array}$} & \multicolumn{2}{|r|}{ （等级完成和通向更高《国际教育标准分类法》等级） } \\
\hline 44 & 中等后非高等普通教育 & 444 & 公认成功完成一个短线高等普通 ${ }^{\prime}$ 课程（或阶段）但不够等级完成 \\
\hline 45 & 中等后非高等职业教育 & 454 & 公认成功完成一个短线高等职业 ${ }^{\prime}$ 课程（或阶段）但不够等级完成 \\
\hline 54 & 短线高等普通教育1 & 540 & 未进一步定义 ${ }^{2}$ \\
\hline 55 & 短线高等职业教育1 & 550 & 未进一步定义 ${ }^{2}$ \\
\hline 56 & 短线高等定向未定教育 ${ }^{3}$ & 560 & 未进一步定义 ${ }^{2}$ \\
\hline \multicolumn{4}{|c|}{$\begin{array}{l}\text { 2. 包括公认成功完成短线高等教育的一个课程, 足够《国际教育标准分类法》5级完成, 或学士或等同水平的一个课程或 } \\
\text { 课程的一个阶段但不够《国际教育标准分类法》6级完成。 } \\
\text { 3. 用于《国际教育标准分类法》6级, 如果高等等级的学术和专业定向缺乏国际同意的定义。 }\end{array}$} \\
\hline
\end{tabular}




\section{《国际教育标准分类法》6级 学士或等同水平}

\section{A. 主要特点}

224. 设置《国际教育标准分类法》6级课程, 即学士或等同水平, 通常是为了给参加者提供中间层面 的学术 / 或专业知识、技艺和能力, 获得第一学位或等同资格证书。本级课程一般以理论为基 础, 但可包括实践成分, 接触最新的研究和 / 或最好的专业实践。传统上由大学和等同的高等教 育机构提供。

225. 本级的授课通常由一般要求已经达到《国际教育标准分类法》7或8级或在所工作领域取得资深专业 经验的职工以讲课的形式来进行。本级课程不必包含完成一个研究课题或论文，但是如果这样做， 该研究课题或论文不如《国际教育标准分类法》7或8级高级，独立或受更多指导。

226. 进入这些课程, 一般要求成功完成《国际教育标准分类法》3或4级并通向高等教育。进入可能取决 于课目选择和 / 或在《国际教育标准分类法》3和 / 或4级达到的成绩。另外, 可能要求参加并成功 通过入学考试。成功完成《国际教育标准分类法》5级后有时候也可能进入或转入《国际教育标准 分类法》6级。一旦完成《国际教育标准分类法》6级课程后, 这些人可继续至《国际教育标准分类 法》7级（硕士或等同水平）受教育，但是并非所有《国际教育标准分类法》6级课程都通向《国际 教育标准分类法》7级。《国际教育标准分类法》6级课程通常不给予直接通向《国际教育标准分类 法》8级课程（博士或等同水平）。

227. 划入《国际教育标准分类法》6级的课程有多种提法, 例如英语 “bachelor's programme (学士课 程）”、法语 “licence，（学士学位）”、或英语 “first university cycle（第一个大学周期）”。然 而, 重要的是要注意, 与 “学士”类似名称的课程, 如果满足第228段所述标准, 应只能包括在《国 际教育标准分类法》6级。出于国际可比性目的, 术语 “学士或等同水平 (bachelor's or equivalent level）"用来标示《国际教育标准分类法》6级。

\section{B. 分类标准}

228. 在学士或等同水平的定义方面, 以下标准是相关的：

\section{主要标准}

a）基于理论和 / 或专业的内容（见第224段）；

b）入学要求（见第226段）;

c）（第一学位）课程的最少累计持续时间（见第229段）；和

d）在国家学位和资格证书结构中的定位（见第230段）。

\section{次要标准}

a）职工资格证书（见第231段）；和

b）不直接通向《国际教育标准分类法》8级课程（见第226段）。 
229. 本级第一学位课程一般在高等等级有3至4年全日制学习的持续时间。那些通过学分积累而授予学位 的系统, 要求有可比的时间量与强度。

230. 本级课程通常授予高等教育中的第一学位和等同资格证书（尽管某些个人在《国际教育标准分类 法》6级课程注册前也许完成一个《国际教育标准分类法》5级资格证书）。它们可能包括基于理论 的学习, 也包括实践成分和 / 或包含一段工作经历。内容复杂程度与学士课程等同的有 4 年以上持 续时间的长线第一学位课程包括在本级。另外, 授予第二或其它学位的课程可包括在《国际教育标 准分类法》6级, 如果其在内容的复杂程度上与同一教育系统的已分类为本级的课程等同, 并且满 足其它主要标准。本级的第二或其它学位课程一般有1至2年的持续时间, 常常是以专业为导向, 比 第一学位更加专门化, 但不包含总体上更为复杂的内容。《国际教育标准分类法》6级课程不必要 求准备一篇有份量的论文或论著。

231. 如果合适, 某些教职人员具有《国际教育标准分类法》8级资格证书的要求, 在有如此要求的教 育系统中, 是本级教育课程的一个好的替代标准。这可用来把《国际教育标准分类法》5级课程 从《国际教育标准分类法》6级课程区分开来。

\section{C. 跨《国际教育标准分类法》等级课程}

232. 不适用

\section{D. 补充标准}

233. 两个标准可用来区分《国际教育标准分类法》6级教育课程:

- 课程定向（见第234段）；和

- 课程持续时间和在国家学位和资格证书结构中的定位（见第235段）。

\section{课程定向}

234. 以下两个定向类别是可用的:

- 学术; 和

- 专业。

\section{课程持续时间和在国家学位和资格证书结构中的定位}

235. 以下四个关于持续时间和课程在国家学位和资格证书结构中的定位的子类别是为《国际教育标准分 类法》6级课程定义的:

- 学士级或等同水平的第一学位中的阶段（或课程），有少于3年的累计理论持续时间（在高等教育 等级），因此不够完成《国际教育标准分类法》6级;

- 学士级或等同水平的第一学位课程，有3到4年的累计理论持续时间（在高等教育级别）;

- 学士级或等同水平的长线第一学位课程, 有4年以上的累计理论持续时间（在高等教育级别）; 和

- 学士级或等同水平的第二或其它学位课程（成功完成一个学士或等同课程后）。 


\section{E 包括在《国际教育标准分类法》6级中的其它课程}

236. 本级包括在教育内容的复杂程度上等同于已归入本级课程的成人教育或继续教育课程。

\section{F. 《国际教育标准分类法》6级教育课程的分类}

237. 使用两个补充标准允许报告定向类别与课程持续时间或在国家学位和资格证书结构中的定位子类 别。用于《国际教育标准分类法》6级的编码在表13中提供。

\section{表13.《国际教育标准分类法》6级教育课程分类编码（ISCED-P）}

\begin{tabular}{|c|c|c|c|}
\hline \multicolumn{2}{|r|}{$\begin{array}{l}\text { 类别 } \\
\text { (定向) }\end{array}$} & $\begin{array}{c}\text { 子类别 } \\
\text { (持续时间和定位) }\end{array}$ & 说明 \\
\hline \multirow[t]{4}{*}{64} & \multirow{4}{*}{$\begin{array}{l}\text { 学士或等同水平, } \\
\text { 学术 }\end{array}$} & 641 & 不够等级完成 \\
\hline & & 645 & 第一学位（3-4年） \\
\hline & & 646 & 长线第一学位（4年以上） \\
\hline & & 647 & 第二或其它学位, 在成功完成一个学士或等同课程后 \\
\hline \multirow[t]{4}{*}{65} & \multirow{4}{*}{$\begin{array}{l}\text { 学士或等同水平, } \\
\text { 专业 }\end{array}$} & 651 & 不够等级完成 \\
\hline & & 655 & 第一学位（3-4年） \\
\hline & & 656 & 长线第一学位（4年以上） \\
\hline & & 657 & 第二或其它学位, 在成功完成一个学士或等同课程后 \\
\hline \multirow[t]{4}{*}{66} & \multirow{4}{*}{$\begin{array}{l}\text { 学士或等同水平, } \\
\text { 定向未定 }^{1}\end{array}$} & 661 & 不够等级完成 \\
\hline & & 665 & 第一学位（3-4年） \\
\hline & & 666 & 长线第一学位（4年以上） \\
\hline & & 667 & 第二或其它学位, 在成功完成一个学士或等同课程后 \\
\hline
\end{tabular}




\section{G. 《国际教育标准分类法》6级受教育程度的分类}

238. 在受教育程度方面, 从成功完成课程（在第一学位前）的阶段获得公认的中间资格证书, 如果不够 《国际教育标准分类法》6级完成, 则划分为《国际教育标准分类法》5级。参加但没有公认成功完 成《国际教育标准分类法》6级的首个课程, 在确定受教育程度等级方面不加考虑。

239. 从成功完成《国际教育标准分类法》7级（硕士或等同水平 - 或是一个长线第一学位, 或是完成学 士课程后的一个第二学位）首个课程的阶段获得的公认中间资格证书, 如果不够《国际教育标准分 类法》7级完成，则划分为受教育程度方面《国际教育标准分类法》6级。

240. 与《国际教育标准分类法》6级有关的受教育程度的分类编码如表14所示。

\section{表14.《国际教育标准分类法》6级受教育程度分类编码（ISCED-A）}

\begin{tabular}{|c|c|c|c|}
\hline \multicolumn{2}{|r|}{ 类别（定向） } & 子类别 & 说明 \\
\hline 54 & 短线高等普通教育 & 540 & 未进一步定义 ${ }^{1}$ \\
\hline 55 & 短线高等职业教育 & 550 & 末进一步定义 1 \\
\hline 56 & 短线高等教育, 定向未定 ${ }^{2}$ & 560 & 未进一步定义 ${ }^{1}$ \\
\hline 64 & 学士或等同水平, 学术 & 640 & 未进一步定义 ${ }^{3}$ \\
\hline 65 & 学士或等同水平, 专业 & 650 & 未进一步定义 ${ }^{3}$ \\
\hline 66 & 学士或等同水平, 定向未定 ${ }^{2}$ & 660 & 未进一步定义 ${ }^{3}$ \\
\hline
\end{tabular}

1. 公认成功完成学士级或等同水平的一个课程或课程的一个阶段但不够《国际教育标准分类法》6级完成。

2. 用于《国际教育标准分类法》6级和7级，如果高等水平的学术和专业定向缺乏国际同意的定义。

3. 包括公认成功完成学士或等同水平的一个课程, 足够《国际教育标准分类法》6级完成, 或硕士或等同水平的一个课程 或课程的一个阶段但不够《国际教育标准分类法》7级完成。 


\section{《国际教育标准分类法》7级 硕士或等同水平}

A. 主要特点

241. 设置《国际教育标准分类法》 7 级课程, 或硕士或等同水平, 通常是为了给参加者提供高级的学 术 / 或专业知识、技艺和能力, 获得第二级学位或等同资格证书。本级课程可有大量的研究成分, 但还不够授予博士资格证书。一般来说，本级课程以理论为基础，但可包括实践成分，接触最新研 究和 / 或最好的专业实践。传统上由大学和其它高等教育机构提供。

242. 本级的授课通常由一般要求已经达到《国际教育标准分类法》7或8级的职员以讲课的形式来进行。 本级课程可能包含完成一个高于《国际教育标准分类法》6级但低于8级的研究课题或论文。

243. 进入为准备第二或其它学位的《国际教育标准分类法》7级课程一般要求成功完成《国际教育标准 分类法》6或7级课程。在为准备等同于硕士的第一学位的长线课程的情况中，入学要求成功完成通 向高等教育的《国际教育标准分类法》3或4级课程。进入这样的课程可能取决于课目选择和 / 或在 《国际教育标准分类法》3和 / 或4级达到的成绩。另外，可能要求参加并成功通过入学考试。《国 际教育标准分类法》7级课程有比《国际教育标准分类法》6级课程明显更加复杂的内容, 通常更加 专业。完成时，个人可继续至《国际教育标准分类法》8级（博士水平教育）的教育，尽管并非所 有《国际教育标准分类法》7级课程给予直接通向《国际教育标准分类法》8级。

244. 划入《国际教育标准分类法》7级的课程可有多种提法, 诸如英语 “master programmes（硕士课 程) ”、法语 “magister (硕士学位) ”。然而, 重要的是注意有与 “硕士” 类似名称的课程, 如 果满足第245段所述标准，应只包括在《国际教育标准分类法》7级。出于国际可比性目的，术语

“硕士或等同水平（master or equivalent level）”用来标示《国际教育标准分类法》7级。

\section{B. 分类标准}

245. 在硕士或等同水平定义方面, 如下标准是相关的:

\section{主要标准}

a）基于理论和 / 或专业的内容（见第241段）；

b）国家学位和资格证书结构中的定位（见第246和247段）；和

c）入学要求（见第243段）。

\section{次要标准}

a) 长线第一学位课程的最短累计持续时间（见第247段）；和

b) 直接通向《国际教育标准分类法》8级课程（见第249段）。 
246. 本级课程通常是为在获得《国际教育标准分类法》6 或7级课程的第一学位后的第二或其它学位作准 备。除非已划在《国际教育标准分类法》6级（见第230段），等同资格证书，如研究生专业资格证 书，也划分为《国际教育标准分类法》7级。

247. 为准备长线第一学位 / 资格证书, 有至少 5 年的持续时间的课程, 如果在内容复杂度方面等同于硕 士级的课程, 包括在本级。这样的课程通常要求准备一篇有份量的论文或论著。在这种情况下, 授 予的学位 / 资格证书直接通向《国际教育标准分类法》8级或等同于已分类为《国际教育标准分类 法》7级的第二或其它学位课程的课程。高度专门化的专业学习（例如医学、牙科、兽医学和某些 情况下的法学或工程学）, 有与高等教育类似或更长的累计持续时间, 无论从广度还是从深度上都 包含等同的内容, 尽管通常不准备一篇论文或论著, 也包括在本级。

248. 本级第二学位或其它学位课程一般有 1 至 4 年全日制学习的持续时间。通过学分积累而授予学位的教 育系统要求有可比的时间量与强度。高等教育级别的学习累计持续时间因此持续从通常 5 年至 8 年或 甚至更长。

249. 给予直接通向《国际教育标准分类法》8级的高等教育课程通常划分在《国际教育标准分类法》7级。 但是，并非所有《国际教育标准分类法》7级课程提供通向《国际教育标准分类法》8级。

\section{C. 跨《国际教育标准分类法》等级课程}

250. 不适用。

\section{D. 补充标准}

251. 两个标准对《国际教育标准分类法》7级教育课程加以区分:

- 课程定向（见第252段）；和

- 在国家学位和资格证书结构中的定位（见第253段）。

\section{课程定向}

252. 以下两个定向类别是可用的:

- 学术; 和

-专业。

\section{在国家学位和资格证书结构中的定位}


253. 以下四个在国家学位和资格证书结构中定位的类别是为《国际教育标准分类法》7级课程定义的：

- 第一学位中的阶段（或课程），在硕士或等同水平，有少于5年的累计理论持续时间（在高等教育 级别），因此不够完成《国际教育标准分类法》7级;

- 硕士或等同水平的长线第一学位课程，有至少5年的累计理论持续时间（在高等教育级别）（不要 求先前的高等教育）;

- 硕士或等同水平的第二或其它学位课程（成功完成一个学士或等同水平课程后）; 和

-硕士或等同水平的第二或其它学位课程（成功完成另一个硕士或等同水平课程后）。

\section{E. 包括在《国际教育标准分类法》7级中的其它课程}

254. 《国际教育标准分类法》7级包括可授予研究资格证书的课程, 明确的目的是训练参加者进行原创 性研究, 但是不到博士学位等级。这些课程通常达到许多与《国际教育标准分类法》8级同样的标 准，尽管趋于较短的持续时间（从高等教育开始后5至6年的累计持续时间），一般缺少学生寻求高 级研究资格证书所要求的独立程度, 为进入《国际教育标准分类法》8级课程做准备。本等级内按 照其在国家学位和资格证书结构中的定位进行分类。

\section{F. 《国际教育标准分类法》7级教育课程的分类}

255. 使用两个补充标准允许报告定向类别与在国家学位和资格证书结构中的定位子类别。用于《国际教 育标准分类法》7级的编码在表15中提供。

\section{G. 《国际教育标准分类法》7级的受教育程度分类}

256. 在受教育程度方面，从成功完成在硕士或等同等级的第一学位中的阶段（或课程）获得的公认中间 资格证书，但不够《国际教育标准分类法》7级完成，则划为《国际教育标准分类法》6级。参加但 没有公认成功完成《国际教育标准分类法》7级的任何第一学位、或成功完成学士或等同课程后的 《国际教育标准分类法》7级第二或其它学位，在确定受教育程度等级时不加考虑。

257. 从成功完成博士或等同等级的阶段（课程）获得的公认中间资格证书，如果不够《国际教育标准分 类法》8级完成, 则划为受教育程度方面的《国际教育标准分类法》7级。

258. 与《国际教育标准分类法》7级有关的受教育程度的分类编码如表 16 所示。 


\section{表15.《国际教育标准分类法》7级教育课程分类编码（ISCED-P）}

\begin{tabular}{|c|c|c|c|}
\hline & $\begin{array}{l}\text { 类别 } \\
\text { (定向) }\end{array}$ & $\begin{array}{l}\text { 子类别 } \\
\text { (定位) }\end{array}$ & 说明 \\
\hline \multirow[t]{4}{*}{74} & \multirow{4}{*}{$\begin{array}{l}\text { 硕士或等同水 } \\
\text { 平, 学术 }\end{array}$} & 741 & 不够等级完成 \\
\hline & & 746 & 长线第一学位（至少5年） \\
\hline & & 747 & 第二或其它学位（成功完成一个学士或等同课程后） \\
\hline & & 748 & 第二或其它学位（成功完成一个硕士或等同课程后） \\
\hline \multirow[t]{4}{*}{75} & \multirow{4}{*}{$\begin{array}{l}\text { 硕士或等同水 } \\
\text { 平, 专业 }\end{array}$} & 751 & 不够等级完成 \\
\hline & & 756 & 长线第一学位（至少5年） \\
\hline & & 757 & 第二或其它学位（成功完成一个学士或等同课程后） \\
\hline & & 758 & 第二或其它学位（成功完成一个硕士或等同课程后） \\
\hline \multirow[t]{4}{*}{76} & \multirow{4}{*}{$\begin{array}{l}\text { 硕士或等同水 } \\
\text { 平, 定向未定 }{ }^{1}\end{array}$} & 761 & 不够等级完成 \\
\hline & & 766 & 长线第一学位（至少5年） \\
\hline & & 767 & 第二或其它学位（成功完成一个学士或等同课程后） \\
\hline & & 768 & 第二或其它学位（成功完成一个硕士或等同课程后） \\
\hline
\end{tabular}

\section{表16.《国际教育标准分类法》7级受教育程度分类编码（ISCED-A）}

\begin{tabular}{|c|c|c|c|}
\hline \multicolumn{2}{|r|}{ 类别（定向） } & 子类别 & 说明 \\
\hline 64 & 学士或等同水平, 学术 & 640 & 未进一步定义 1 \\
\hline 65 & 学士或等同水平, 专业 & 650 & 未进一步定义 ${ }^{1}$ \\
\hline 66 & 学士或等同水平, 定向未定 ${ }^{2}$ & 660 & 未进一步定义 ${ }^{1}$ \\
\hline 74 & 硕士或等同水平, 学术 & 740 & 未进一步定义 ${ }^{3}$ \\
\hline 75 & 硕士或等同水平, 专业 & 750 & 未进一步定义 ${ }^{3}$ \\
\hline 76 & 硕士或等同水平, 定向未定 ${ }^{2}$ & 760 & 未进一步定义 ${ }^{3}$ \\
\hline $\begin{array}{l}1 . \\
2 . \\
3 .\end{array}$ & $\begin{array}{l}\text { 认成功完成硕士或等同水平的- } \\
\text { 于《国际教育标准分类法》6级 } \\
\text { 括公认成功完成硕士或等同水 } \\
\text { 课程的一个阶段但不够《国际 }\end{array}$ & $\begin{array}{l}\text { 《国际教 } \\
\text { 业定向缺 } \\
\text { 准分类; }\end{array}$ & $\begin{array}{l}\text { 分类法》7级完成。 } \\
\text { 洞意的定义。 } \\
\text { 完成，或博士或等同水平的一个课程 }\end{array}$ \\
\hline
\end{tabular}




\section{《国际教育标准分类法》8级 博士或等同水平}

\section{A. 主要特点}

259. 《国际教育标准分类法》8级课程, 或博士或等同水平, 主要是为获得高级研究资格证书而设置。 本级课程致力于高级学习和原创性研究, 一般仅由以研究为导向的高等教育机构如大学提供。学术 领域和专业领域都有博士课程。

260. 《国际教育标准分类法》8级通常以提交并答辩一篇对所在研究领域的知识有重要贡献的论文, 论 著或具有发表质量的书面作品为结束。所以, 这些课程一般地以研究为基础, 而不仅仅是科目学 习。在某些教育系统中, 《国际教育标准分类法》8级课程含有非常有限的科目学习, 或者根本就 没有, 追求博士学位的人大多独立地从事研究或在小组中接受不同程度的指导。在某些教育系统 中, 从事博士研究的人, 除了注册为博士学生, 还被大学聘为初级研究员或研究助理。

261. 进入《国际教育标准分类法》8级课程或初级研究员职位, 通常要求成功完成特定的《国际教育标 准分类法》7级课程。《国际教育标准分类法》8级资格证书获得者给予进入要求高学术技能的专门 职业、和政府及工业中的研究职位、以及在《国际教育标准分类法》6、7、8级提供教育的教育机 构中的研究和教学职位。

262. 划入《国际教育标准分类法》8级课程可有多种说法, 如 “PhD (博士学位)”, “DPhil（哲学博 士）”，“D.Lit（文学博士）”，“D.Sc（理学博士）”，“LL.D（法学博士）, “Doctorate（博士 学位)”或类似的名称。然而重要的是注意与 “博士”一样名称的课程, 如果满足第263段所述标准, 应只包括在《国际教育标准分类法》8级。出于国际可比性目的, 术语 “博士或等同水平 (doctoral or equivalent level）" 用于标示《国际教育标准分类法》8级。

\section{B. 分类标准}

263. 在博士或等同水平定义方面, 以下标准是相关的：

\section{主要标准}
a）书面作业要求（（见第264段）;
b）入学要求（见第261段）；和
c）等级的最短持续时间（见第265段）。

\section{次要标准}

a）特定职业要求的博士学位 / 资格证书（见第266段）。 
264. 成功完成《国际教育标准分类法》8级课程要求提交一篇论文, 论著或具有发表质量的等同书面作 业, 作为原创性研究的结果, 代表对所在研究领域知识有重要贡献。

265. 《国际教育标准分类法》8级要求至少 3 年相当于全日制的学习，在高等教育有至少 7 年全日制教育 的总累计持续时间。

266. 获得《国际教育标准分类法》8级资格证书通常是进入提供《国际教育标准分类法》6、7、8级课程 的教育机构担任教职以及政府和行业中的研究职位的前提条件。

\section{C. 跨《国际教育标准分类法》等级课程}

267. 不适用。

D. 补充标准

268. 一个标准可用来对《国际教育标准分类法》8级教育课程作区分：

- 课程定向（见第269段）。

\section{课程定向}

269. 以下两个定向类别是相关的:

- 学术; 和

-专业。

\section{E. 包括在《国际教育标准分类法》8级中的其它课程}

270. 第二个高级研究资格证书或更高的博士头衔通常也划入《国际教育标准分类法》8级, 这些资格证 书要求在学术生涯的颇后阶段, 而且通常是没有正规指导的情况下, 提交第二篇有份量的研究（比 第一篇博士论文更进一步）。例子有 “habilitation（大学任教资格）”、或俄语 “doktor nauk（博 士）”资格证书，尽管大多数教育系统只有授予博士学位或等同资格证书的一个高级研究资格。这 些证书通常不与某个教育课程挂钩（例如候选人通常不在通向这些资格证书的课程中注册）。第二 个研究资格证书在《国际教育标准分类法》中没有单独编码。由大学给与的基于其它考虑而不是任 何研究工作的名誉博士不包括在《国际教育标准分类法》8级。

\section{F. 《国际教育标准分类法》8级教育课程分类}

271. 《国际教育标准分类法》8级的教育课程, 或是完整的博士水平课程, 或是不够完成国际教育标准 分类法》8级的博士水平的阶段（或课程）。使用一个补充标准允许报告定向类别。用于《国际教 育标准分类法》8级的编码如表17所示。 
表17.《国际教育标准分类法》8级教育课程分类编码（ISCED-P）

\begin{tabular}{|c|c|c|c|}
\hline \multicolumn{2}{|r|}{ 类别（定向） } & 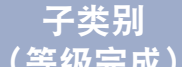 & 说明 \\
\hline \multirow[t]{2}{*}{84} & \multirow[t]{2}{*}{ 博士或等同水平, 学术 } & 841 & 不够等级完成 \\
\hline & & 844 & 足够等级完成 \\
\hline \multirow[t]{2}{*}{85} & \multirow[t]{2}{*}{ 博士或等同水平, 专业 } & 851 & 不够等级完成 \\
\hline & & 854 & 足够等级完成 \\
\hline \multirow[t]{2}{*}{86} & \multirow[t]{2}{*}{ 博士或等同水平, 定向未定 ${ }^{1}$} & 861 & 不够等级完成 \\
\hline & & 864 & 足够等级完成 \\
\hline
\end{tabular}

\section{G. 《国际教育标准分类法》8级受教育程度分类}

272. 在受教育程度方面, 从成功完成在博士或等同等级的第一学位中的阶段（或课程）获得的公认中间 资格证书, 但不够《国际教育标准分类法》8级完成, 则划入《国际教育标准分类法》7级。参加 却没有公认成功完成《国际教育标准分类法》8级的任何首个课程, 在确认受教育程度等级时不加 考虑。

273. 与《国际教育标准分类法》8级有关的受教育程度的分类编码如表18所示。

\section{表18.《国际教育标准分类法》8级受教育程度分类编码（ISCED-A）}

\begin{tabular}{|c|c|c|c|}
\hline \multicolumn{2}{|r|}{ 类别（定向） } & 子类别 & 说明 \\
\hline 74 & 硕士或等同水平, 学术 & 740 & 未进一步定义 ${ }^{1}$ \\
\hline 75 & 硕士或等同水平，专业 & 750 & 未进一步定义 1 \\
\hline 76 & 硕士或等同水平, 定向未定 ${ }^{2}$ & 760 & 未进一步定义 1 \\
\hline 84 & 博士或等同水平, 学术 & 840 & 未进一步定义 \\
\hline 85 & 博士或等同水平, 专业 & 850 & 未进一步定义 \\
\hline 86 & 博士或等同水平, 定向未定 ${ }^{2}$ & 860 & 未进一步定义 \\
\hline
\end{tabular}

1. 公认成功完成博士或等同水平的一个课程或课程的一个阶段但不够《国际教育标准分类法》8级完成。

2. 用于《国际教育标准分类法》7和8级, 如果高等水平的学术和专业定向缺乏国际同意的定义。 


\section{第十章《国际教育标准分类法》2011版与1997版的等级对应关系}

274. 本章描述《国际教育标准分类法》2011版分类与早期的1997版框架的等级之间的对应（或和谐） 关系。

275. 在《国际教育标准分类法》2011版中，0级包含了所有年龄的早期儿童教育，包括非常年幼的儿 童。根据教育内容的复杂程度, 课程细分为 2 个类别：早期儿童教育开发（编码 $010 ）$ 和学前教育 （编码020）。早期儿童教育开发课程（编码010）一般是给低于3岁的儿童设置的。这在《国际教 育标准分类法》2011版作为一个新类别采用, 不包括在1997版中。学前教育（编码020）完全对应 1997版中的0级。

276. 《国际教育标准分类法》2011版1级, 初等教育, 对应1997版1级。

277. 《国际教育标准分类法》2011版2级和3级, 初级中等教育和高级中等教育, 主要对应1997版2级和 3级。但是, 由于所用标准和次要标准的变动, 《国际教育标准分类法》2011版的实施也许不同于 1997版（即, 某些课程划入与以前不同的等级）。这样的差异可能影响一些国家的时间序列数据。

278. 与《国际教育标准分类法》1997版相比，2011版简化了2级和3级中的补充标准:

- 《国际教育标准分类法》2011版的课程定向仅分为职业课程和普通课程。1997版将职业前教育单 独分类。这样的课程没有提供劳务市场相关的资格证书，现在主要划入普通教育;

- 《国际教育标准分类法》2011版只认定一组通向更高等级教育的课程。相比之下, 1997版根据后 续教育的类型将通向更高等级教育区分成类别 $A$ 和 $B$ 。2011版子类别“等级完成和通向更高《国 际教育标准分类法》等级” 与1997版中类别A和B合起来相对应;

- 《国际教育标准分类法》2011版将不通向更高《国际教育标准分类法》等级的课程细分为子类 别 “无等级完成”，“部分等级完成” 和 “等级完成”。2011版中这三个子类别大体与1997版中 类别C和3级 “C短线” 和 “C长线” 相对应。

279. 《国际教育标准分类法》2011版4级 - 中等后非高等教育 - 与《国际教育标准分类法》1997版4级 大致对应。但是, 那些可获得等同于高级中等普通教育资格证书的课程, 在《国际教育标准分类 法》2011版中划为3级, 而在1997版中常划分在4级。此外, 由于所用标准及次要标准的变动,

《国际教育标准分类法》2011版的实施与1997版可能不同。这样的不同可能影响某些国家的时间 序列数据资料。

280. 《国际教育标准分类法》2011版简化了4级的定向标准，如同2级和3级（见第194、153、175 段）。2011版中子类别“通向更高等级” 和 “不通向更高等级”与1997版中的去向类别A和B分 别对应。 
281. 《国际教育标准分类法》2011版有4个高等教育等级, 而1997版只有2个高等教育等级。《国际 教育标准分类法》2011版中的5、6、7级一起与1997版中的5级相对应。《国际教育标准分类 法》2011版中的8级对应1997版中的6级。

282. 《国际教育标准分类法》2011版, 与1997版相比, 简化了高等教育级别中的补充标准:

- 在《国际教育标准分类法》2011版5级中，第二个数字将职业课程从普通课程中区分出来。而 在1997版中, 这样的区别并不存在。在《国际教育标准分类法》2011版中, 给区分学术和专业 定向留有可能的余地, 等待国际上研究出《国际教育标准分类法》6至8级的学术和专业定向的 统一定义。

- 在《国际教育标准分类法》2011版6级和7级中, 分类的第三个数字按照持续时间和在国家学位和 资格证书结构中的定位加以区分，用于诸如入学和毕业率的统计计算。而在1997版中，用课程定 向或 “课程类型” 将《国际教育标准分类法》5A区分成第一学位课程和第二学位课程以及其它学 位课程（对应于2011版中6级和7级合在一起）。课程分类的第三个数字区分6级和7级的第一学位 和第二学位或其它学位。

283. 表19显示1997版与2011版《国际教育标准分类法》等级的对应（或和谐）关系。

表19.《国际教育标准分类法》1997版与2011版等级的对应关系

\begin{tabular}{|c|c|}
\hline $\begin{array}{c}\text { 《国际教育标准分类法》 } \\
2011 \text { 版 }\end{array}$ & $\begin{array}{c}\text { 《国际教育标准分类法》 } \\
1997 \text { 版 }\end{array}$ \\
\hline 《国际教育标准分类法》0级1类 & - \\
\hline 《国际教育标准分类法》0级2类 & 《国际教育标准分类法》0级 \\
\hline 《国际教育标准分类法》1级 & 《国际教育标准分类法》1级 \\
\hline 《国际教育标准分类法》2级 & 《国际教育标准分类法》2级 \\
\hline 《国际教育标准分类法》3级 ${ }^{*}$ & 《国际教育标准分类法》3级 \\
\hline 《国际教育标准分类法》4级* & 《国际教育标准分类法》4级 \\
\hline 《国际教育标准分类法》5级 & \multirow{3}{*}{ 《国际教育标准分类法》5级 } \\
\hline 《国际教育标准分类法》6级 & \\
\hline 《国际教育标准分类法》7级 & \\
\hline 《国际教育标准分类法》8级 & 《国际教育标准分类法》6级 \\
\hline
\end{tabular}

284. 表20和表21显示《国际教育标准分类法》2011版与1997版的详细对应（或和谐）关系，其中包括 补充标准、类别、子类别。 
表20.《国际教育标准分类法》2011版与1997版的详细对应关系：0至4级

\begin{tabular}{|c|c|c|c|c|}
\hline \multicolumn{5}{|c|}{ 《国际教育标准分类法》2011版 } \\
\hline 等级标示 & 等级 & 类别 & 子类别 & 子类别注释 \\
\hline 早期儿童教育开发 & \multirow{2}{*}{0} & 01 & 010 & 教育课程针对未满三岁儿童 \\
\hline 学前教育 & & 02 & 020 & \\
\hline 初等教育 & 1 & 10 & 100 & \\
\hline \multirow{8}{*}{ 初级中等教育 } & \multirow{8}{*}{2} & \multirow{4}{*}{$\begin{array}{l}24 \\
\text { 普通 }\end{array}$} & 241 & 不够等级完成或部分等级完成, 不直接通向高级中等教育 \\
\hline & & & 242 & 部分等级完成, 不直接通向高级中等教育 \\
\hline & & & 243 & 等级完成, 不直接通向高级中等教育 \\
\hline & & & 244 & 等级完成, 直接通向高级中等教育 \\
\hline & & \multirow{4}{*}{$\begin{array}{c}25 \\
\text { 职业 }\end{array}$} & 251 & 不够等级完成或部分等级完成, 不直接通向高级中等教育 \\
\hline & & & 252 & 部分等级完成, 不直接通向高级中等教育 \\
\hline & & & 253 & 等级完成, 不直接通向高级中等教育 \\
\hline & & & 254 & 等级完成, 直接通向高级中等教育 \\
\hline \multirow{8}{*}{ 高级中等教育 } & \multirow{8}{*}{3} & \multirow{4}{*}{$\begin{array}{l}34 \\
\text { 普通 }\end{array}$} & 341 & 不够等级完成或部分等级完成, 不直接通向高等教育 \\
\hline & & & 342 & 部分等级完成, 不直接通向高等教育 \\
\hline & & & 343 & $\begin{array}{l}\text { 等级完成, 不直接通向第一个高等课程（但可给予直接通向中等后 } \\
\text { 非高等教育） }\end{array}$ \\
\hline & & & 344 & $\begin{array}{l}\text { 等级完成, 直接通向第一个高等课程（也可给予直接通向中等后非 } \\
\text { 高等教育） }\end{array}$ \\
\hline & & \multirow{4}{*}{$\begin{array}{c}35 \\
\text { 职业 }\end{array}$} & 351 & 不够等级完成或部分等级完成, 不直接通向高等教育 \\
\hline & & & 352 & 部分等级完成, 不直接通向高等教育 \\
\hline & & & 353 & $\begin{array}{l}\text { 等级完成, 不直接通向第一个高等课程（但可给予直接通向中等后 } \\
\text { 非高等教育） }\end{array}$ \\
\hline & & & 354 & $\begin{array}{l}\text { 等级完成, 直接通向第一个高等课程（也可给予直接通向中等后非 } \\
\text { 高等教育） }\end{array}$ \\
\hline \multirow{6}{*}{ 中等后非高等教育 } & \multirow{6}{*}{4} & \multirow{3}{*}{$\begin{array}{l}44 \\
\text { 普通 }\end{array}$} & 441 & 不够等级完成, 不直接通向高等教育 ${ }^{2}$ \\
\hline & & & 443 & 等级完成, 不直接通向第一个高等课程 ${ }^{2}$ \\
\hline & & & 444 & 等级完成, 直接通向第一个高等课程 ${ }^{2}$ \\
\hline & & \multirow{3}{*}{$\begin{array}{c}45 \\
\text { 职业 }\end{array}$} & 451 & 不够等级完成, 不直接通向高等教育 ${ }^{2}$ \\
\hline & & & 453 & 等级完成, 不直接通向第一个高等课程 ${ }^{2}$ \\
\hline & & & 454 & 等级完成, 直接通向第一个高等课程 ${ }^{2}$ \\
\hline
\end{tabular}

1. 可能包括以前划分为《国际教育标准分类法》4级的课程, 如果等同于《国际教育标准分类法》3级

2. 不包括之前划分为《国际教育标准分类法》4级的课程, 如果等同于《国际教育标准分类法》3级 


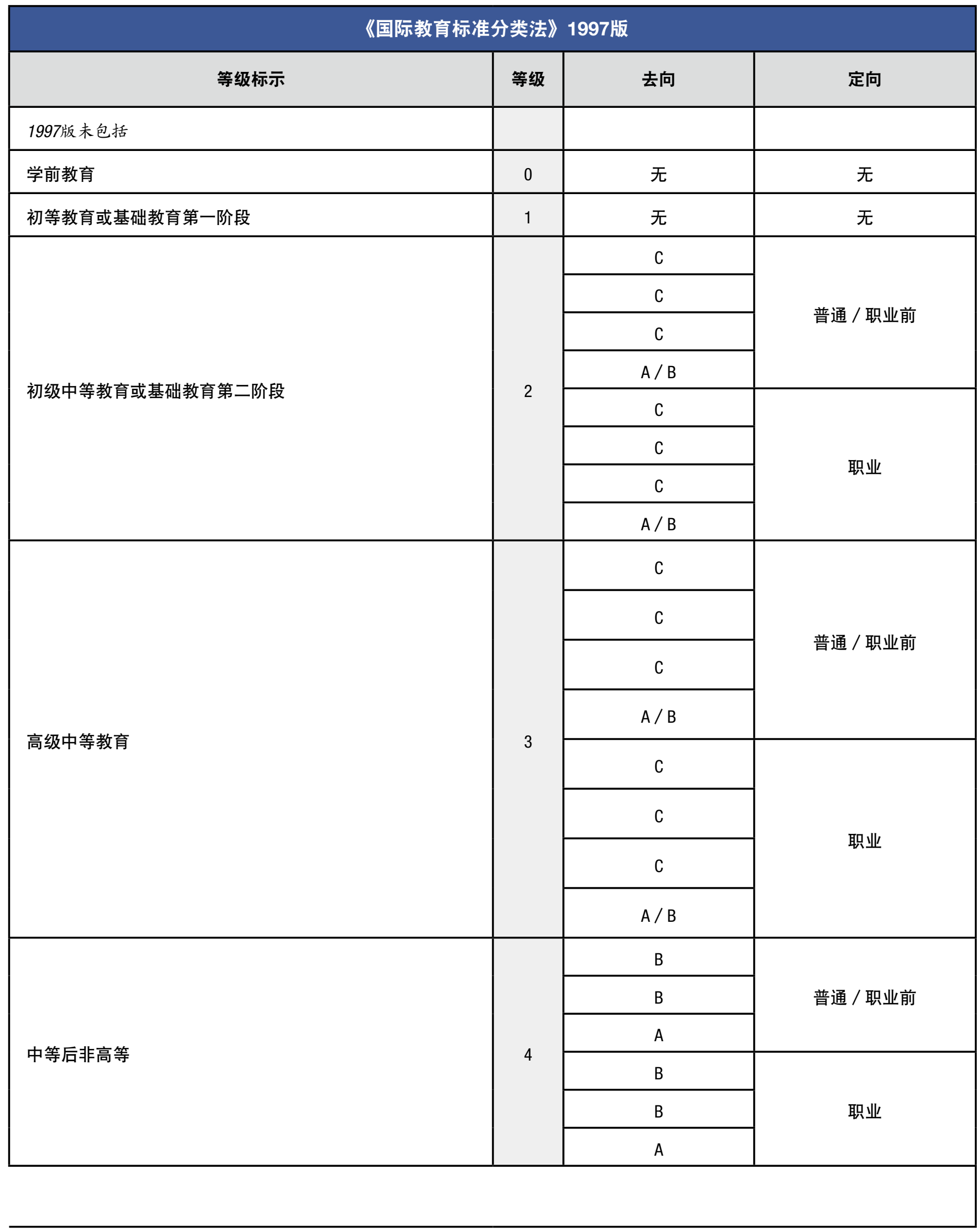


表21.《国际教育标准分类法》2011版与1997版的详细对应关系：高等教育

\begin{tabular}{|c|c|c|c|c|c|}
\hline & & & & 国际教育标准分类法》2011版 & \\
\hline 等级标示 & 等级 & 类别 & 子类别 & 子类别注释 & 注释 \\
\hline \multirow{4}{*}{$\begin{array}{l}\text { 短线 } \\
\text { 高等教育 }\end{array}$} & \multirow{4}{*}{5} & \multirow{2}{*}{$\begin{array}{l}54 \\
\text { 普通 }\end{array}$} & 541 & 不够等级完成 & \\
\hline & & & 544 & 足够等级完成 & \\
\hline & & \multirow{2}{*}{$\begin{array}{l}55 \\
\text { 职业 }\end{array}$} & 551 & 不够等级完成 & \\
\hline & & & 554 & 足够等级完成 & \\
\hline \multirow{4}{*}{$\begin{array}{l}\text { 学士或 } \\
\text { 等同水平 }\end{array}$} & \multirow{4}{*}{6} & \multirow{4}{*}{$\begin{array}{c}66^{1} \\
\text { 定向未定 }\end{array}$} & 661 & 不够等级完成 & \\
\hline & & & 665 & 第一学位（3-4年） & \\
\hline & & & 666 & $\begin{array}{l}\text { 长线第一学位（多于>4年）（学士或 } \\
\text { 等同课程） }\end{array}$ & \\
\hline & & & 667 & $\begin{array}{l}\text { 第二或其它学位（在一个学士或等同 } \\
\text { 课程后） }\end{array}$ & 如果等同于已划为 6 级的课程。 \\
\hline \multirow{4}{*}{$\begin{array}{l}\text { 硕士或 } \\
\text { 等同水平 }\end{array}$} & \multirow{4}{*}{7} & \multirow{4}{*}{$\begin{array}{c}76^{1} \\
\text { 定向未定 }\end{array}$} & 761 & 不够等级完成 & \\
\hline & & & 766 & $\begin{array}{l}\text { 长线第一学位（至少 } \geq 5 \text { 年）（硕士或 } \\
\text { 等同课程）（） }\end{array}$ & $\begin{array}{l}\text { 除非等同于已划为6级的课程, 否则 } \\
\text { 归入666。 }\end{array}$ \\
\hline & & & 767 & $\begin{array}{l}\text { 第二或其它学位（在一个学士或等同 } \\
\text { 课程） }\end{array}$ & \\
\hline & & & 768 & $\begin{array}{l}\text { 第二或其它学位（在一个硕士或等同 } \\
\text { 课程） }\end{array}$ & \\
\hline \multirow{2}{*}{$\begin{array}{l}\text { 博士或 } \\
\text { 等同水平 }\end{array}$} & \multirow{2}{*}{8} & \multirow{2}{*}{$\begin{array}{c}86^{1} \\
\text { 定向未定 }\end{array}$} & 861 & 不够等级完成 & \\
\hline & & & 864 & 足够等级完成 & 只直接通向博士学位的课程。 \\
\hline
\end{tabular}

1. 在《国际教育标准分类法》 6,7 和 8 级中学术和专业课程的对应（或和谐）关系与那些定向未定课程的是一致的。 


\begin{tabular}{|c|c|c|c|c|}
\hline \multicolumn{5}{|c|}{ 《国际教育标准分类法》1997版 } \\
\hline 等级标示 & 等级 & 类型 & 定位 & 高等教育累计持续时间 \\
\hline \multirow{12}{*}{ 高等教育, 第一阶段 } & 5 & B & 无 & $<2$ 年 \\
\hline & 5 & B & 无 & $\geq 2$ 年 \\
\hline & 5 & B & 无 & $<2$ 年 \\
\hline & 5 & B & 无 & $\geq 2$ 年 \\
\hline & 5 & A & 中间 & $<3$ 年 \\
\hline & 5 & A & 第一 & 3-4年 \\
\hline & 5 & A & 第一 & $>4$ 年 \\
\hline & 5 & A & 第二 / 其它 & $\geq 4$ 年 \\
\hline & 5 & A & 中间 & $<4$ 年 \\
\hline & 5 & A & 第一 & $\geq 5$ 年 \\
\hline & 5 & A & 第二 / 其它 $2^{\text {nd }}$ & $\geq 4-5$ 年 \\
\hline & 5 & A & 第二 / 其它 $2^{\text {nd }}$ & $\geq 6$ 年 \\
\hline \multirow{2}{*}{ 高等教育, 第二阶段 } & 6 & 无 & 无 & 无 \\
\hline & 6 & 无 & 无 & 无 \\
\hline
\end{tabular}


附件I《国际教育标准分类法》2011版潜在教育路径

\section{附件| 《国际教育标准分类法》2011版潜在教育路径}

图2.《国际教育标准分类法》2011版潜在教育路径

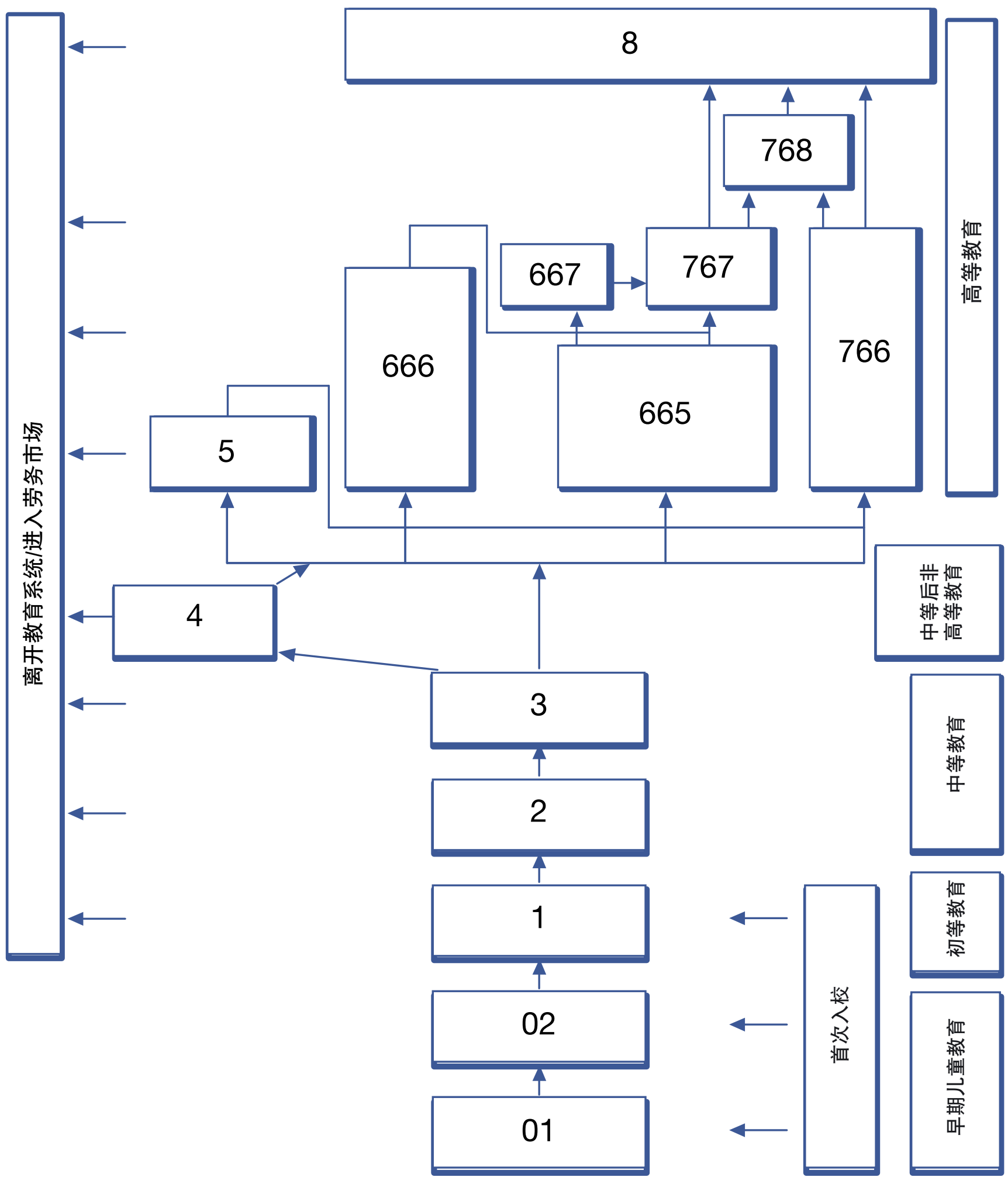




\section{附件|| 教育课程编码}

0 早期儿童教育

01 早期儿童教育开发

010 早期儿童教育开发

02 学前教育

020 学前教育

\section{1 初等教育}

10 初等教育

100 初等教育

\section{2 初级中等教育}

24 普通

241 不够等级完成或部分等级完成, 不直接通向高级中等教育

242 足够部分等级完成, 不直接通向高级中等教育

243 足够等级完成, 不直接通向高级中等教育

244 足够等级完成, 直接通向高级中等教育

25 职业

251 不够等级完成或部分等级完成, 不直接通向高级中等教育

252 足够部分等级完成, 不直接通向高级中等教育

253 足够等级完成, 不直接通向高级中等教育

254 足够等级完成, 直接通向高级中等教育

\section{3 高级中等教育}

34 普通

341 不够等级完成或部分等级完成, 不直接通向高等教育

342 足够部分等级完成, 不直接通向高等教育

343 足够等级完成, 不直接通向高等教育

344 足够等级完成, 直接通向高等教育

35 职业

351 不够等级完成或部分等级完成, 不直接通向高等教育

352 足够部分等级完成, 不直接通向高等教育

353 足够等级完成, 不直接通向高等教育

354 足够等级完成, 直接通向高等教育

\section{4 中等后非高等教育}

44 普通

441 不够等级完成，不直接通向高等教育

443 足够等级完成, 不直接通向高等教育

444 足够等级完成, 直接通向高等教育

45 职业

451 不够等级完成, 不直接通向高等教育

453 足够等级完成, 不直接通向高等教育

454 足够等级完成, 直接通向高等教育

\section{5 短线高等教育}

54 普通 $^{1}$

541 不够等级完成

544 足够等级完成

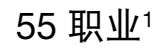

551 不够等级完成

554 足够等级完成 


\section{6 学士或等同水平}

64 学术

641 不够等级完成

645 第一学位 (3至4年)

646 长线第一学位 (4年以上)

647 第二或其它学位（在一个学士或等同课程后）

65 专业

651 不够等级完成

655 第一学位 (3至4年)

656 长线第一学位 (4年以上)

657 第二或其它学位（在一个学士或等同课程后）

66 定向未定 ${ }^{1}$

661 不够等级完成

665 第一学位 (3至4年)

666 长线第一学位 (4年以上)

667 第二或其它学位（在一个学士或等同课程后）

\section{7 硕士或等同水平}

74 学术

741 不够等级完成

746 长线第一学位（至少5年）

747 第二或其它学位（在一个学士或等同课程后）

748 第二或其它学位（在一个硕士或等同课程后）

75 专业

751 不够等级完成

756 长线第一学位（至少5年）

757 第二或其它学位（在一个学士或等同课程后）

758 第二或其它学位（在一个硕士或等同课程后）

76 定向未定 ${ }^{1}$

761 不够等级完成

766 长线第一学位（至少5年）

767 第二或其它学位（在一个学士或等同课程后）

768 第二或其它学位（在一个硕士或等同课程后）

\section{8 博士或等同水平}

84 学术

841 不够等级完成

844 足够完成等级

85 专业

851 不够等级完成

854 足够完成等级

86 定向未定 $^{1}$

861 不够等级完成

864 足够完成等级

\section{9 别处末分类}

99 别处未分类

999 别处未分类

1. 用于对高等学术和专业定向缺乏国际公认定义的情况。 


\section{附件||| 受教育程度编码}

0 低于初等教育

01 从未上过一个教育课程

010 从未上过一个教育课程

02 某些早期儿童教育

020 某些早期儿童教育

03 某些初等教育（没有等级完成）

030 某些初等教育（没有等级完成）

\section{1 初等教育}

10 初等

100 包括公认成功完成一个初级中等课程但不够等级完成或部分等级完成

\section{2 初级中等教育 1}

24 普通 $^{1}$

242 部分等级完成, 不直接通向高级中等教育

243 等级完成, 不直接通向高级中等教育

244 等级完成, 直接通向高级中等教育 1

25 职业 $^{1}$

252 部分等级完成, 不直接通向高级中等教育

253 等级完成, 不直接通向高级中等教育

254 等级完成, 直接通向高级中等教育 1

\section{3 高级中等教育 1}

34 普通 1

342 部分等级完成, 不直接通向高等教育

343 等级完成, 不直接通向高等教育

344 等级完成, 直接通向高等教育 1

35 职业 $^{1}$

352 部分等级完成, 不直接通向高等教育

353 等级完成, 不直接通向高等教育

354 等级完成, 直接通向高等教育 1

\section{4 中等后非高等教育 1}

44 普通 $^{1}$

443 等级完成, 不直接通向高等教育

444 等级完成, 直接通向高等教育 1

45 职业 $^{1}$

453 等级完成, 不直接通向高等教育

454 等级完成, 直接通向高等教育 1 


\section{5 短线高等教育 1}

54 普通 1,2

540 无进一步定义 ${ }^{1}$

55 职业 1,2

550 无进一步定义 ${ }^{1}$

56 定向未定 ${ }^{1,2}$

560 无进一步定义 ${ }^{1}$

\section{6 学士或等同水平 1}

64 学术 1

640 无进一步定义 ${ }^{1}$

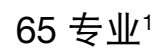

650 无进一步定义 ${ }^{1}$

66 定向未定 ${ }^{1,2}$

660 无进一步定义 ${ }^{1}$

\section{7 硕士或等同水平 1}

74 学术 $^{1}$

740 无进一步定义 1

75 专业 ${ }^{1}$

750 无进一步定义 1

76 定向未定 ${ }^{1,2}$

760 无进一步定义 1

\section{8 博士或等同水平 1}

84 学术 $^{1}$

840 无进一步定义

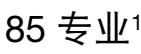

850 无进一步定义

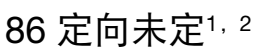

860 无进一步定义

\section{9 别处末分类}

99 别处未分类

999 别处末分类

1. 包括成功完成给定等级的一个课程, 足够等级完成; 或成功完成《国际教育标准分类法》更高等级的一个课程或课程的一个阶 


\section{附件IV 教育的大类和学科}

285. 本版教育学科对《国际教育标准分类法》1997版框架没作变动。在1999年为联合国教科文组织开 发的编码草案的基础上, 联合国教科文组织统计研究所计划开发关于教育与培训学科的三等级层次 分类方法。该编码方法过去10多年一直为欧盟统计局和经合发组织所使用，但要求进一步更新。 一旦联合国教科文组织大会正式通过关于教育与培训学科的新分类方法, 它将确定为一个单独的分 类法, 从《国际教育标准分类法》各等级中分离出来, 本版《国际教育标准分类法》的该章节将被 撤除。

286. 有25个教育学科, 组织成九个大类。建议对跨学科或多学科的课程按多数原则进行分类, 即划入学 生花费时间最多的教育学科。

《国际教育标准分类法》的学科 :

0 普通课程

01 基础课程学前、初级、初等、中等教育普通基础课程等。

\section{8 识字和识数}

简单的和实用的识字和识数。

\section{9 个人发展}

提高个人技能, 如行为能力、智力、个人组织能力、生活方向课程。

\section{1 教育}

\section{4 师资培训和教育科学}

学前、幼儿园、小学、职业、实用、非职业课目、成人教育、师资培训者及残疾儿童方 面的师资培训。普通和专门的师资培训课程。

教育科学: 非职业和职业课目的课表设置。教育评估, 测试与测量, 教育研究, 其它教 育科学。

\section{2 人文学科和艺术}

\section{1 艺术}

美术：素描、绘画、雕塑;

表演艺术：音乐、戏剧、舞蹈、杂技;

图形和视听艺术：摄影、电影、音乐制作、广播和电视制作、印刷和出版;

设计：工艺技巧。

\section{2 人文学科}

宗教和神学;

外国语言和文化：活的或 “死的”语言及其文学、区域研究;

母语：通用语言或方言及其文学;

其它人文学科: 口译与笔译、语言学、比较文学、历史、考古学、哲学、伦理学。 


\section{3 社会科学、商业和法律}

\section{1 社会及行为科学}

经济学、经济史、政治学、社会学、人口学、人类学（不包括体质人类学）、民族学、 未来学、心理学、地理学（自然地理除外）、和平及冲突研究、人权。

\section{2 新闻学和信息}

新闻学; 图书馆员及图书馆学; 博物馆员及类似资料库员;

文献技术;

档案科学。

\section{4 商业和管理}

零售、市场、销售、公共关系、房地产;

金融、银行、保险、投资分析;

会计、审计、簿记;

管理、公共管理、机构管理、人事管理;

秘书及办公室工作。

\section{8 法律}

地方法官、“公证员”、法律（通法、国际法、劳动法、海事法等）、法学、法律史。

\section{4 科学}

\section{2 生命科学}

生物学、植物学、细菌学、毒物学、微生物学、动物学、昆虫学、鸟类学、遗传学、生 物化学、生物物理学、其它有关学科, 不包括临床医学和兽医学。

\section{4 自然科学}

天文学和空间科学、物理学、其它有关学科、化学、其它有关学科、地质学、地球物理 学、矿物学、体质人类学、自然地理和其它地球科学、气象学和其它大气科学包括气候 研究、海洋科学、火山学、古生态学。

\section{6 数学和统计学}

数学、运筹学、数值分析、精算科学、统计学和其它有关领域。

\section{8 计算}

计算机科学: 系统设计、计算机程序、数据处理、网络、操作系统 一 仅含软件开发（硬 件开发应属于工程领域）。

\section{5 工程、制造和建筑}

\section{2 工程学和工程行业}

工程绘图、机械、金工、电力、电子、电信、能源与化工、车辆维护、测绘。 


\section{4 制造与加工}

食品与饮料加工、纺织、服装、鞋袜、皮件、材料（木材、纸、塑料、玻璃等）、采矿 和提炼。

\section{8 建筑学与建筑工程}

建筑学与城镇规划：结构建筑学、景观建筑学、社区规划、图表绘制;

建筑、施工;

土木工程。

6 农业

62 农业、林业和渔业

农业、作物与畜牧生产、农学、畜牧业、园艺学和园林、林业和林产品技术、自然公 园、野生动植物、渔业、渔业科学和技术。

\section{4 兽医}

兽药、兽医助理

\section{7 卫生和福利}

\section{2 卫生}

医学：解剖学、传染病学、细胞学、生理学、免疫学和免疫血液学、病理学、麻醉学、 儿科学、产科学与妇科学、内科、外科、神经科学、精神病学、放射学、眼科学;

医疗服务：公共卫生服务、卫生学、药学、药理学、疗法、康复、假肢、验光配镜、营 养学;

护理：基本护理、助产;

牙科: 牙科助理、口腔卫生、牙科试验室技术员、齿科学。

76 社会服务

社会照料：残疾人照料、保育、青少年服务、老年服务;

社会工作：咨询、别处未加分类的福利。

\section{8 服务行业}

\section{1 个人服务}

酒店和餐饮业、旅行和旅游业、体育和休闲、理发、美容及其它个人服务：清洁、洗 衣、干洗、化妆、家政学。

\section{4 运输服务}

航海技术、船舶职员、航海学、空中乘务、空中交通管制、铁路运营、道路机动车辆运 营、邮政。

\section{5 环境保护}

环境保持、控制与保护, 空气和水污染控制, 劳动保护与安全。

\section{6 安全服务}

财产和人员保护：警察工作与相关的执法工作、犯罪学、防火与消防、公民安全;

军事。

\section{不明及未分类的课目}

（此类并非分类法本身中的一部分，但在收集资料时，“99”用来指 “不明或未分类的学科”。） 


\section{附件 V 《国际教育标准分类法》中的非正规教育：进一步的议题}

287. 《国际教育标准分类法》2011版定义了非正规教育（第39段），提供了非正规教育的类型（第40 段），强调非正规教育通常不通向更高等级教育，除非正规教育系统（第41段）适当地确认其有 效，并建议采用内容等同和 / 或产生的资格证书等同准则来对非正规教育课程分类（第42段）。

288. 本附件描述了非正规教育课程一些附加特点。非正规课程的概念需要进一步开发, 以便为国际统计 的目的而对非正规课程进行准确的测算。有少量非正规课程的国际数据收集活动的例子存在, 可供 咨询以提供特别的建议。

289. 《国际教育标准分类法》2011版的第40段规定，根据各国的具体情况，非正规教育和培训可以包括 以下课程:

i) 有助于成人和青年扫盲以及失学儿童的教育（初期教育的替代课程）；和

ii) 侧重于生活技能、工作技能和社会或文化发展的课程。

后一条可包括:

- 在工作场所为提高或调整现有资格证书和技能而进行的培训, 为失业或经济上非就业人员进行的 培训。

- 为追求个人发展的学习活动（在个人的私人（闲暇）时间）。

290. 非正规教育课程的异质性意味着, 很难提供一个一般性指南, 将其应用在统计工具中达到国际可比 性的目的。《国际教育标准分类法》2011版建议采用内容等同准则对非正规教育课程进行分类。内 容等同将非正规课程与《国际教育标准分类法》中具有同样内容的正规课程联系起来。原则上，这 就容许将非正规课程划分等级。例如, 一个成人教育课程如果符合《国际教育标准分类法》1 级的 内容标准，则可划入《国际教育标准分类法》1级。

291. 在成功完成一个非正规教育课程时所授予的资格证书通常能支持教育课程的分类。例如, 非正规职 业培训的分类可基于与正规教育课程比较，成功完成非正规职业培训后所授予的资格证书（若有） 的等级和类型的等同性。在同一教育系统内课程与资格证书之间建立内容等同性，国家和地区资格 证书框架, 若存在的话, 能提供指导。《国际教育标准分类法》2011版建议对正规和非正规课程分 别进行一次透明的鉴定。

292. 非正规教育可由各种团体提供, 包括教育机构、私人企业、非政府组织、和公共机构。在某些情况 中, 提供正规教育的同一机构也提供非正规教育和培训。但是，与正规教育课程一样，提供者的类型 既不能作为主要标准来划分非正规教育和培训的等级，也不能作为主要标准区分正规和非正规教育。 
293. 非正规课程的持续时间可能很短。特别地, 工作和闲暇时间的培训活动可能考虑了与特定工作和私 人生活情况有关的特别实用目的。因此, 非正规课程常被描述为（培训）课目。

294. 非正规课程常常针对的是获取具体情况下的实际知识、技艺或能力, 因而较少注重理论学习。例 如，一个正规课程可以教计算机科学（即为了获取一个IT-工程师的公认资格证书），而非正规课程 也许教授工作中实际使用计算机的特殊 IT教程。

295. 替代课程主要存在于某些正规教育系统欠发达或范围受局限的国家。这些课程不被教育当局公认为 正规的。它们通常覆盖《国际教育标准分类法》0-3级, 并由包括非政府组织 (NGO) 在内的私人 组织提供。

296. 尽管非正规教育是《国际教育标准分类法》的一个公认部分, 出于国际可比性和可行性的考虑, 国 际数据收集活动（图谱分析、调查和普查等）的范围可能局限于正规教育。因此，正规和非正规课 程的界线是重要的, 应给予特别的注意。然而, 在现阶段, 《国际教育标准分类法》2011版对非正 规课程或任何相关的非正规资格证书进行图谱分析没有给出特别的建议。 


\section{附件VI 词汇表}

部分完成《国际教育标准分类法》第2级（Partial completion of an ISCED level 2)。成功 完成满足《国际教育标准分类法》第2级最少 2 年的课程，累计持续时间从《国际教育标准分类 法》1级开始至少 8 年, 作为《国际教育标准分类法》第2级序列课程的一部分, 但不是该等级序 列的最后课程，这些课程不给予直接通向《国际教育标准分类法》第3级。

部分完成《国际教育标准分类法》第3级（Partial completion of an ISCED level 3）。成功 完成满足《国际教育标准分类法》第3级最少 2 年的课程，累计持续时间从《国际教育标准分类 法》1级开始至少 11 年, 作为《国际教育标准分类法》第3级序列课程的一部分, 但不是该等级 序列的最后课程，这些课程不给予直接通向《国际教育标准分类法》更高等级。

参加（Participation）。出席或接受一个教育课程、或其阶段或单元。

参加者（Participant）。出席或参加一个教育课程、或其阶段或单元的人。

常规教育（Regular education）。提供给不需特殊需要教育个人的初期教育。

成功完成一个教育课程（Successful completion of an educational programme）。实现一个 教育课程的学习目标, 通常通过评估所获得的知识、技艺和能力来验证。成功完成一个教育课程 常采用授予教育资格证书来记录。

成人教育（Adult education）。特别针对被社会认定为成人的教育，旨在改善他们的技术和专业 资格证书, 进一步开发他们的能力, 丰富他们的知识, 以便完成正规教育的一个等级, 或在特定 的学科获得、刷新或更新他们的知识、技艺和能力。还包括那些可以被称为 “继续教育”、“回 流教育”、或 “二次机会教育”的教育。

初等教育（《国际教育标准分类法》1级）（Primary education（ISCED level 1））。初等教 育提供的学习和教育活动, 通常是为了给学生提供阅读、写作和数学的基本技能（即识字和算 术）, 以及为学习和理解知识和个人发展的核心领域、准备初级中等教育奠定一个牢固的基础。 侧重于基础层面的学习，几乎不涉及专业知识。

初级中等教育（《国际教育标准分类法》2级）（Lower secondary education (ISCED level 2) ）。《国际教育标准分类法》2级课程, 或初级中等教育, 一般是在《国际教育标准分 类法》1级的基础上设计的。通常, 其教育目标是为终身学习和人力开发奠定基础, 教育系统由 此可以扩展进一步的教育机会。本级课程通常围绕更加以课目为导向的课表进行组织, 就广泛的 课目引入理论概念。

初期教育（Initial education）。个人首次进入劳务市场之前所受的正规教育, 即当他们通常处 于全日制教育时。因此, 它以被社会看作是儿童、青年和年轻人为对象。通常发生在被设计为连 续教育路径的体制中的教育机构。

单元 (Module)。单元式课程中一个课目或课目的一部分。一个单元可单独学习, 也可与其它 的单元组合在一起。 
单元式课程（Modular programmes）。学生能组合不同的课目或单元，灵活地安排教育内容的 教育课程。单元式课程因此通常没有明确界定的顺序。

低于初等教育（《国际教育标准分类法》受教育程度0级）（Less than primary（ISCED-Alevel0））。 受教育程度的一个广泛等级, 包括从未参加教育、参加过某些早期儿童教育和 / 或参加某些初等教育。

第二或其它学位（Second or further degree）。成功完成《国际教育标准分类法》6级或7级所 授予的学位, 要求事先成功完成一个《国际教育标准分类法》6级或7级学位以进入所在的教育 课程。

第一学位（First degree）。成功完成《国际教育标准分类法》6级或7级所授予的学位, 不需要 事先完成《国际教育标准分类法》6级的任何学位来进入所在的教育课程。

典型持续时间（Typical duration）。以学年表示，学生成功完成一个教育课程所花费的时间，假 定正常的全日制参与。

二次机会教育（Second chance education）。特别针对以下这些人的教育：由于各种原因， 从未上过学校, 或在完成所注册的教育等级之前离开, 或完成该等级但希望进入其尚未取得资格 的一个教育课程或职业。参加者通常比给定的《国际教育标准分类法》等级课程对象年龄组的典 型年龄大（但未必是成人）。有时也称为“连接课程（bridging programmes）”或 “再整合课 程 (re-integration programmes)"。

非正规（教育）资格证书（Non-formal （educational）qualification）。完成非正规教育中一 个教育课程的学习目标而授予的资格证书，相关的国家教育当局不公认其等同于正规资格证书。

非正规教育（Non-formal education）。教育提供者的有制度的、有目的、有计划的教育。非 正规教育的特点是在个人终生学习的进程中对正规教育的一个附加、替代和 / 或补充。提供非正 规教育的目的是为了保障所有个人接受教育的权利。它顾及各种年龄的人但无须采用连续的路径 结构; 可能持续时间短和 / 或强度低; 它通常以短课程、讨论班或研讨班的形式提供。由非正规 教育所得到的资格证书多数不被相关国家或地方教育当局公认为正式或等同于正式的资格证书, 或者根本就没有资格证书。非正规教育可以包括有助于成人和青年扫盲、失学儿童的教育、以及 有关生活技能、工作技能和社会或文化发展的课程。

非正式学习（Informal learning）。有目的的或有意的但不是有制度的学习形式。它们缺乏像正 规或非正规教育那样的组织和结构。非正式学习可包括在家庭、工作场所、地方社区和日常生活 中, 基于自我导向、家庭导向或社会导向的学习活动。

高等教育（《国际教育标准分类法》5至8级）（Tertiary education（ISCED levels 5-8））。高 等教育建立在中等教育之上, 在专业化的教育学科提供学习活动。它是高度复杂和高度专业化的 学习。高等教育包括通常所理解的学术教育, 但还包括高级职业或专业教育。 
高级中等教育（《国际教育标准分类法》3级）（Upper secondary education (ISCED level 3) ) 。《国际教育标准分类法》3级课程, 或高级中等教育, 通常旨在完成为高等教育 做准备的中等教育, 或者提供与就业有关的技能, 或者两者都是。本级的课程给学生提供比初 级中等教育（《国际教育标准分类法》2级课程）更多样、更专业和程度更深的授课。这些课程 更加差异化，选修范围增加和能力组有更多。

公认资格证书（Recognized qualification）。相关国家教育当局对在达到一个教育课程的学习 目标后授予的资格证书所作的正式批准。

基于工作的教育（Work-based education）。发生在工作环境中的教育活动, 通常是职业教育 课程。其目的是在有经验的工作人员或培训者的指导下，通过实践授课和参加工作活动，以期达 到特定学习目标。

教育 (Education) 。社会有意地将积累起来的信息、知识、理解、态度、价值、技艺、能力和 行为从上一代传给下一代的过程。它牵涉到引起学习的交流。

教育的学科（Field of education）。一个教育课程、课目或单元所覆盖的内容的门类、分支 或领域。通常称为 “课目 (subject) ”或 “专业 (discipline)”。也称为 “学习领域（field of study)"。

教育等级（Levels of education）。一套有序的集合，用以根据学习经历以及一个课程应予传 授的知识、技艺和能力的阶段性变化, 将教育课程分组。《国际教育标准分类法》等级反映了 一个教育课程内容从基础到综合的复杂程度和专业程度。

教育活动（Educational activity）。有意的活动，涉及旨在引起学习的某种交流形式。

教育机构 (Educational institution)。以提供教育为主要目的建立的机构, 如学校、学院、大 学或培训中心。这样的机构通常由相关国家教育当局或等同部门认证或批准。教育机构也可由如 宗教团体、特殊利益集团或私人教育和培训企业这样的盈利和非盈利的组织来运营。

教育课程（Education programme）。一套连贯或序列的教育活动，为在一段持续的时期内 达到预定的学习目标或完成一组具体的教育任务而设计和组织的。在一个教育课程中, 教育活 动还可以分组为次部分, 即各国所说的“课 (courses)”、“单元 (Modules)”、“单位 (units)”和 / 或 “课目 (subjects) ”。一个教育课程可以包含通常不定格为课、单位或 单元的主要内容, 诸如游戏教学活动、工作经历期、研究课题、和准备论著。

教育提供者（Education provider）。以提供教育为主要或者次要目标的组织。这可以是一个公 共教育机构，也可是一个私人企业、非政府组织或非教育公共团体。

阶段（Stage）。教育课程的一个次等级, 根据理论持续时间或要完成的一组特定单元或要达到 的学分划分。一个特定的阶段具有区别于同一教育课程的其它阶段的特征, 可以单独地授予一个 中间资格证书。 
结业（Graduation）。成功完成一个教育课程。如果一个毕业生同时在两个或两个以上课程注 册并成功完成，那么他可能拥有多于一次的结业（甚至在同一学年）。

进入（Entry）。开始参加一个或一组教育等级、课程、或其阶段或单元的行为。

课（目）（Course）。一个授课单位, 包括一个特定的教育学科或几个相关的教育学科中的一 序列教育活动。也可称为 “单元 (module)”、“单位 (unit)” 或 “课目 (subject) ”。

累计持续时间 (Cumulative duration)。一序列教育课程的总理论持续时间。在《国际教育标 准分类法》中, 从《国际教育标准分类法》1级或3级开始或自高等教育开始的累积持续时间, 常要求用来区分教育课程。

理论持续时间（Theoretical duration）。以学年表示, 教授一个教育课程所花费的时间, 假定 正常的全日制参与。

年级（Grade）。初期教育中授课的一个特定阶段, 通常覆盖一个学年。同一个年级的学生通常 年龄相仿。也称“班（class）”、“届（cohort）”或“年（year）”。

培训（Training）。为达到特定的学习目标而设置的教育, 特别是在职业教育中。《国际教育标 准分类法》中教育的定义包括培训。

普通教育 (General education)。系指为发展学习者的普通知识、技艺和能力以及读写和计算 技能而设计的教育课程, 通常为参加者进入《国际教育标准分类法》同级或更高级教育课程做准 备, 并为终身学习奠定基础。普通教育课程通常是以学校或学院为基础的。普通教育包括那些为 学生进入职业教育做准备的教育课程, 但是不为从事某一特定的职业或行业或某类职业或行业做 准备, 也不直接授予与劳务市场相关的资格证书。

其它学位（Further degree）。见第二或其它学位。

入学人数（Entrants）。在一个或一组教育等级、课程、或其阶段或单元的开始时注册的人 数, 不考虑年龄大小。

受教育程度（Educational attainment）。一个人成功完成的最高《国际教育标准分类法》教育 等级。这通常是通过测定的, 成功完成的最高教育课程一般用一个公认的资格证书来证明。公认 的中间资格证书通常划为比该课程本身低一等级。

双轨制教育课程（Dual system educational programmes）。将学校或学院教育与基于工作的 教育结合在一起的课程。两部分都是有份量的，（即多于一次单个实习或偶尔上课），尽管基于 工作的部分经常占到课程时间的50\%或更多。

顺带学习或无约束学习（Incidental or random learning）。如各种未经组织过的学习或者所涉 及的交流的并不是为了引起学习。顺带学习或无约束学习可能是没为有意的教育或学习活动而设 计的日常活动、事件或交流的附带结果。例子可能包括会议过程中发生的学习, 收听电台节目或 观看不是按教育课程设计的电视节目。 
特殊需要教育（Special needs education）。旨在帮助那些个人, 由于各种原因, 需要额外的 支持和合适的教育方法, 才能参加一个教育课程和达到学习目标的学习的教育。原因可能是（但 不限于）身体、行为、智力、情感和社交能力的缺陷。特殊需要教育中的教育课程可采用与并行 的常规教育系统类似的课表, 但根据个人的特别需求, 提供特定的资源（即经特别培训的人员、 装备、或空间）, 在合适的情况下, 调整教育内容和学习目标。这些课程可在已有的教育课程中 提供给单个学生, 或在同一或单独的教育机构中以单独的班级的形式提供。

未成功完成一个教育课程（Unsuccessful completion of an educational programme）。未 达成一个教育课程的学习目标, 尽管出席或参加该教育课程的所有部分（包括最终考试，如果有 的话）。未成功完成意味着对是否达到学习目标进行了一定的评估，但显示出来的所获得的知 识、技艺和能力被判定为不够。

无约束学习（Random learning）。见顺带学习或无约束学习。

学分（Credit）。在一个教育课程期间和结束时, 成功完成课目或单元所得到并加以记录的单 位。基于学生为达到预期学习目标所需要的正常工作量, 学分表示学习量。

学年（Academic year）。学生上课或参加最终考试的年度教学或考试时期, 不考虑短的假期。 可能短于 12 个月, 但一般不短于 9 个月。可能由于一国内的不同教育等级或教育机构类型而变 化。又称为 “school year（校年）”，主要见于高等教育前的等级。

学位（Degree）。成功完成高等教育中一个特定教育课程后（传统上由大学和等同机构）所授 予的教育资格证书。

学习（Learning）。个人通过经历、实践、研究或授课而在信息、知识、理解、态度、价值、技 艺、能力或者行为方面的获取或改变。

学习成果（Learning outcomes）。预期个人成功完成一个教育课程后所掌握的信息、知识、理 解、态度、价值、技艺、能力、或行为的总和。

学习成果评估（Assessment of learning outcomes）。在一个教育课程期间或结束时对个人完 成学习目标的评价, 采用一系列评估方法（书面、口头和实务测试 / 考试、课题和作品组合）。

学习成果验证（Validation of learning outcomes）。采用一系列评估方法（书面、口头和实务 测试／考试、课题和作品组合），对一个人达成学习目标的评价，而不假定是否参加了一个教育 课程。

学习活动（Learning activity）。有意的活动, 个人以学习为目的参加。

学习目标（Learning objectives）。对完成教育或学习活动后所达到的学习成果的详细描述。包 括提高个人、民事、社会和 / 或就业方面的知识、技艺和能力水平。学习目标, 一般与为学习深 造和 / 或从事某个职业或行业或某种职业或行业做准备相关连。 
学校或学院教育 (School-or college-based education)。教育活动在为初期教育课程中儿 童和青少年建立的机构中进行, 目的是通过包括专门学习环境（即实验、音乐室、计算机房或 体育馆）课目在内的教室授课和在教师指导下的群体活动达到特定的学习目标。通常将学生按 年级、年龄和能力水平分组。

一个《国际教育标准分类法》等级的完成（Completion of an ISCED level）。成功完成一个 足够等级完成的教育课程。在《国际教育标准分类法》1和4至8级中, 成功完成一个满足给定 等级的内容和最少持续时间标准的课程, 视为等级完成。在《国际教育标准分类法》2和3级 中, 成功完成任何准予通向更高等级 (即《国际教育标准分类法》2级课程时的3级, 3级课程 时的 5、6或7级）的课程, 算为等级完成, 如同完成满足《国际教育标准分类法》相应等级的 内容、最少持续时间（2年）和累计持续时间标准（即《国际教育标准分类法》2级课程情况下 从 《国际教育标准分类法》1级开始后的8年, 和《国际教育标准分类法》3级课程情况下的 11 年）的任何终端课程。

一个教育课程的毕业生（Graduate of an educational programme）。成功完成一个教育课程 的人。

一个教育课程的完成 (Completion of an educational programme)。参加了一个教育课程 的所有部分（包括最终考试，如有的话），与达到学习目标的任何可能评估的结果无关。

早期儿童教育（《国际教育标准分类法》0级）（Early childhood education（ISCED-P level0））。早 期儿童教育使用整体方法提供学习和教育活动, 以支持儿童早期的认知、体格、社交和情感发 展以及引导年幼儿童进入有组织的家庭外授课, 以开发学术预备必需的某些技能和为进入初等 教育做准备。

正规教育（Formal education）。有制度的、有目的、有计划的教育, 通过公共组织和公认的 私人团体进行, 它们的总和构成一个国家的正规教育系统。正规教育课程因此经相关的国家教 育当局或相当的机构, 比如与国家或地方的教育当局合作的任何其它机构, 来公认。正规教育 主要由初期教育构成。职业教育、特殊需要教育和部分成人教育通常公认为正规教育系统的一 部分。

职业教育（Vocational education）。使学习者获取某种职业或行业或数种职业或行业特定的 知识、技艺和能力的教育课程。职业教育有基于工作的成分（例如实习, 双轨制教育课程）。 成功完成这样的课程将得到由有关国家当局和 / 或劳务市场承认的与劳务市场有关的职业资格 证书。

中等后非高等教育（《国际教育标准分类法》4级）（Post-secondary non-tertiary education (ISCED level 4) ) 。中等后非高等教育（《国际教育标准分类法》4级）（Post-secondary non-tertiary education (ISCED level 4))

中等教育（《国际教育标准分类法》2至3级）（Secondary education（ISCED levels 2-3））。中 等教育提供的学习和教育活动, 是建立在初等教育之上, 既为进入中等后非高等教育、高等教 育做准备, 也为进入劳务市场做准备。大体上说, 中等教育瞄准中等复杂程度的学习。《国际 教育标准分类法》分初级和高级中等教育。 
中间资格证书（Intermediate qualification）。正式确认, 通常采取文件形式, 证明成功完成教 育课程的一个阶段。

注册人数（Enrolment）。在一个给定教育课程、或其阶段或单元正式登记的人数, 不考虑年龄 大小。

资格证书（Qualification）。正式确认, 通常采用文件的形式, 证明成功完成一个教育课程或 课程的某个阶段。获得资格证书的方式有：i）成功完成一个完整教育课程；ii）成功完成一个教 育课程的某个阶段（中间资格证书）；或iii）不考虑对教育课程的参与而对所掌握的知识、技艺 和能力的验证。也可称为 “证书 (credential)”。

最短持续时间（Minimum duration）。一个教育课程的最短理论持续时间, 用于对《国际教 育标准分类法》给定等级的课程进行, 或确定《国际教育标准分类法》给定等级的完成或部分 完成。 
由于各国教育系统的结构和内容各不相同, 《国际教育标准分类法》 (ISCED) 为以可比和统一的 方式发布数据提供了框架。《分类法》有助于各国将国家教育数据转换为国际公认的类别, 从而 使跨国对比成为可能。

《国际教育标准分类法》是《联合国经济与社会分类法国际系列》中的一个参考分类。最初于20世 纪70年代由联合国教科文组织开发, 《国际教育标准分类法》得到持续更新, 以反映全球教育系统 的不断演进。新的2011版《国际教育标准分类法》分类（取代1997年版本）因此提供改善了的定义 和扩张了的范围, 以更好地监测教育的全球态势。为此, 高等教育和早期儿童教育章节做了大幅修 订。此外, 2011版《国际教育标准分类法》还对教育课程和受教育程度使用了新的编码系统。

联合国教科文组织统计研究所是《国际教育标准分类法》的监管机构, 负责其开发、维护、更新 和修订。本统计研究所为在国际数据收集和分析中有效和一致地使用《国际教育标准分类法》提 供指导。

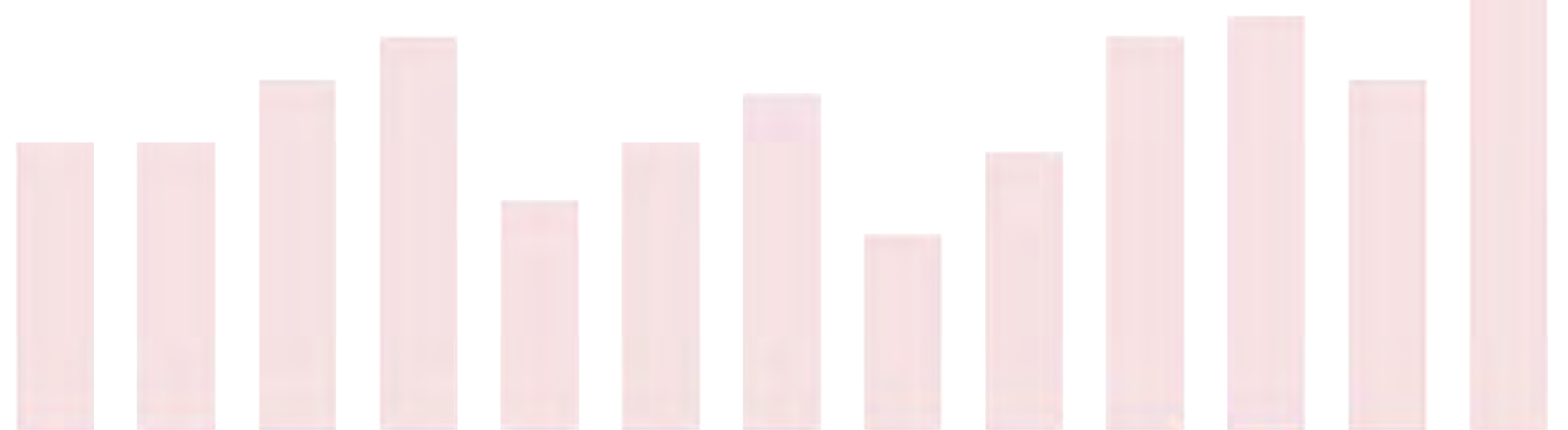

